\title{
BANKRUPTCY EXEMPTIONS: CRITIQUE AND SUGGESTIONS
}

IN order to achieve the bankruptcy goal of compromise between debtor and creditor interests, ${ }^{1}$ an honest bankrupt is not only discharged from most of his previously-incurred obligations, ${ }^{2}$ but is allowed to have a minimum amount of property exempted from distribution among his creditors. ${ }^{3}$ Such exemptions are the result of a legislative reconciliation of two competing social policies. On the one hand, a commercial society's dependence upon credit necessitates the enforcement of borrowers' obligations. Any freedom of assets from legal seizure reduces the moral and legal duty to repay, thereby adding to the creditor's risk of loss and retarding lending. ${ }^{4}$ On the other, in a community which is concerned with the well-being of its individual members, the social cost of leaving a debtor and his family without resources may outweigh the economic disadvantages of immunizing property from the claims of creditors. ${ }^{5}$ As might be expected, the struggle between these policies has engendered political controversy throughout American history, and legislative sympathy with the debtor class has fluctuated with the economic barometer. ${ }^{8}$

1. See generally Glenn, Liquidation 337-74 (1935). Madilachlan, BankRuptcy 1-24 (1956); Moore, Cases on Debrors' and Creditors' Rights 1-1.1 (1955).

The administration of debtors' estates is governed by the Bankruptcy Act of 1898, 30 Stat. 544, as amended, 11 U.S.C. \$\$ 1-112 (1952), as amended, 11 U.S.C. \$§ 32-107 (Supp. $\mathrm{V}, 1958$ ). [Hereinafter cited as Bankruptcy Act. Sections of the act will be cited as they appear in BANKRUPTCX ACT (Collier pamphlet ed. 1956). The corresponding United States Code section numbers may be ascertained by adding 0 to $\S 1,9$ to $\S 2,18$ to $\S \S 3-17,23$ to $\S \S 18-32,28$ to $\S \S 33-54,36$ to $\S \S 55-60$, and 40 to $\S \S 61-72$. The first 72 sections, dealing with "ordinary bankruptcy," are the only ones relevant to this Comment.]

The power to enact a federal bankruptcy act is specifically granted by the Constitution: "... Congress shall have the power ... to establish . . . uniform laws on the subject of Bankruptcies throughout the United States." U.S. Const. art. I, § 8.

Problems peculiar to life insurance exemptions are generally outside the scope of this Comment. For a recent treatment of such exemptions see Riesenfeld, Life Insurance and Creditors' Remedies in the United States, 4 U.C.L.A.L. Rev. 583 (1957).

2. Bankruptcy Act $\S 17$ allows the discharge, with few exceptions, of all provable debts, as defined in $\$ 63$. Generally, only debts arising prior to filing of the petition in bankruptcy are provable. Bankruptcy Act $\S 63(\mathrm{a})$. Discharge will be denied under $\S 14$ (c) if the debtor has committed perjury, concealed or destroyed his property or records, obtained money through a false statement, or failed to explain satisfactorily any loss of any assets. See In re Underhill, 82 F.2d 258 (2d Cir. 1936).

3. Bankruptcy Act § 6 .

4. See U.S. Dep'r of Agriculture, Tech. Bull. No. 288, Farm Mortgage Crenit 1-7 (1932). "The farmer, owning two hundred acres of fine black land [in Texas], might very conservatively show a net worth of over $\$ 30,000 \ldots$ and yet have no basis of credit except, indeed, his character." Schwalst, The Extension of Bank CRedit 32 (1927).

5. "... [T] he State ... [has an interest] ... in its exemption laws, to the end that owners of exempt property and their families shall not be reduced to absolute destitution, thus becoming a charge upon the public.” Slatcoff v. Dezen, 76 .So. 2d 792, 794 (Fla. 1954). See also Haskins, Homestead Exemptions, 63 HARv. L. REv. 1289 (1950).

6. See generally WarRen, BankRUPTCY IN UNITEd States Fistory (1935) [here- 
The first national bankruptcy act, enacted by the Federalists in 1800 after the 1792 and 1797 panics had resulted in widespread imprisonment for debt, ${ }^{7}$ provided only for involuntary proceedings against merchants and traders. ${ }^{8}$ Bankrupts were granted an allowance for support while the proceedings were pending; $;$ and certain wearing apparel and household necessities ${ }^{10}$ plus a small percentage of other assets, varying according to dividends paid to creditors, ${ }^{11}$ could be retained as exempt property. The Jeffersonians, resentful of the act's abuse by wealthy speculators, repealed it three years later..$^{12}$ Despite a severe depression in the 1820 's ${ }^{13}$ and the limitations placed upon

inafter cited as WARREN] ; Poteat, Debtors' Exemptions: A Study in Credit Administration, June 1933 (unpublished thesis in Yale Law Library) [hereinafter cited as PotEst].

7. James Otis of Massachusetts described the need for a bankruptcy law as follows: Misfortune, enterprise, speculation and a spirit of overtrading, have involved thousands in ruin. . . Men fail for millions and though these great leviathans of speculation, after sunk in the ocean for a time, may rise again and revel on the surface, yet the widows and orphans, the fair merchants, industrious tradesmen, and credulous friends, who are involved in the same whirlpool, rise no more. To prevent these mischiefs, we should give to creditors a control over the property of their debtors, so as to stop the fraudulent in their careers, and we should rescue the honest and unfortunate insolvent from the oppression of a vindictive creditor. Quoted in WARREN 17.

8. An Act To Establish a Uniform System of Bankruptcy, ch. 19, $\$ 1,2$ Stat. 19 (1800) [hereinafter cited as Bankruptcy Act of $1800, \S 0,2$ Stat. 00].

9. Bankruptcy Act of $1800, \S 53,2$ Stat. 34. Under present English law the trustee may, with the permission of the Committee of Inspection, make an interim allowance to the bankrupt for the support of himself and his family. Williams, Banrruptcy PracTICE 225, 240, 269-73 (14th ed. 1932).

10. Bankruptcy Act of $1800, \S 5,2$ Stat. 23 .

11. A bankrupt was allowed:

five per cent. upon the nett produce of all the estate that shall be recovered in and received, which shall be paid unto him or her by the assignee . . . in case the nett produce of such estate, after such allowance made, shall be sufficient to pay the creditors of said bankrupt . . . the amount of fifty per cent. on their said debts, respectively, and so as the said five per cent. shall not exceed, in the whole, the sum of five hundred dollars; and in case the nett produce of the said estate shall, over and above the allowance hereafter mentioned, be sufficient to pay the said creditors seventy-five per cent. on the amount of their said debts, respectively, that then the said bankrupt shall be allowed ten per cent. on the amount of such nett produce ... so as such ten per cent. shail not ... exceed the sum of eight hundred dollars; ....

Bankruptcy Act of $1800, \S 34,2$ Stat. 30 . If the estate did not yield $50 \%$ to creditors the bankrupt received "so much money as the commissioners shall think fit to allow, not more than three hundred dollars, nor exceeding three per centum on the nett proceeds. ..." Bankruptcy Act of $1800, \S 34,2$ Stat. 31.

12. Act of Dec. 19, 1803, ch. 6, 2 Stat. 248; see Poteat 6; Warren 19-20. Besides its abuse by the rich, general dissatisfaction over the act resulted from the difficulty of traveling to the unpopular federal courts. Ibid.

13. WARREN 25-26. 
state debtor relief by the Constitution's "obligation of contracts" clause, ${ }^{14}$ no new federal bankruptcy legislation was passed until 1841.

The 1841 act, stemming from a crash touched off by overspeculation in government land, ${ }^{15}$ introduced voluntary bankruptcy proceedings and granted a small exemption for wearing apparel, household furniture and other necessaries worth up to $\$ 300.16$ Since creditors resented the discharge under the act of more than 28,000 bankrupts for one-tenth of their outstanding obligations ${ }^{17}$ and debtors found the low exemptions less beneficial than those provided by most state laws, ${ }^{18}$ the act was repealed after eighteen months. ${ }^{19}$ A period of relative prosperity, and the passage of state laws which ameliorated the effects of mortgage foreclosures and further extended exemptions may explain the abence of federal legislation for the following twenty-five years. ${ }^{20}$ But the economic disorder following the Civil War, precipitated a new bankruptcy act in 1867.21 To satisfy the western states, whose exemption provisions were generally liberal, local exemptions were incorporated for the first time if they exceeded the act's uniform allowance ${ }^{22}$ which, although modeled on its 1841 counterpart raised the dollar value to $\$ 500 .{ }^{23}$ To enlist the sup-

14. "No state shall .. pass any . . law impairing the obligation of contracts." U.S. Const. art. I, \$ 10. See Sturges v. Crowninshield, 17 U.S. (4 Wheat.) 120 (1819) (invalidating a New York statute which allowed discharge of debts incurred prior to passage of the state statute).

When a federal bankruptcy act is in effect, it pre-empts state legislation which provides for a discharge or otherwise closely resembles the federal statute. See generally Radin, What is a Bankruptcy Act?, 20 A.B.A.J. 792 (1934); Johnson v. Star, 287 U.S. 527 (1933) ; International Shoe Co. v. Pinkus, 278 U.S. 261 (1929).

15. See WARREN 52-63.

16. An Act To Establish a Uniform System of Bankruptcy, ch. 9, § 3, 5 Stat. 442 (1841) [hereinafter cited as Bankruptcy Act of $1841, \S 0,5$ stat. 000]. In addition, the assignee (the counterpart of the modern trustee in bankruptcy) had discretion, up to the dollar limit, to designate exemptions "having reference . . . to the family, condition, and circumstances of the bankrupt ...." Bankruptcy Act of 1S41, § 3, 5 Stat. 443.

17. In the short period the act was in effect, debtors received discharges of nearly $\$ 445,000,000$ in obligations upon the surrender of only $\$ 45,000,000$ worth of property. Cong. Grobe, 27th Cong., 3d Sess. 69 (1843).

18. WARREN 82.

19. An Act To Repeal the Bankruptcy Act, ch. 82, 5 Stat. 614 (1843).

20. WARREN S7-SS.

21. 'An Act To Establish a Uniform System of Bankruptcy, ch. 176, 14 Stat. 517 (1867) [hereinafter cited as Bankruptcy Act of 1867, § 0, 14 Stat. 000].

After the Civil War began, debts due Northern merchants from the South were large$1 \mathrm{y}$ wiped out. "In 1861, 913 mercantile houses in New York became insolvent. . . Out of 256 solvent dry goods houses in New York at the beginning of the war, only 16 were solvent at the end of the first year." WARREN 97.

22. Bankruptcy Act of $1867, \S 14,14$ Stat. 523 , quoted at note 23 infra. A previous bill had been defeated because of the failure to incorporate state exemptions. WARREN $100,103$.

23. . . there shall be excepted from the operation of the provisions of this section the necessary household and kitchen furniture, and such other articles and neces- 
port of veterans, a soldier's uniform and equipment were also exempted..4 Expense and corruption in the act's administration caused immediate dissatisfaction, ${ }^{25}$ but the Panic of 1873 and liberalizing amendments forestalled repeal for eleven years. ${ }^{26}$

Following this repeal, growing realization of the need for permanent bankruptcy legislation led to agitation for Congressional action. ${ }^{27}$ The Panic of 1893 and collapse of western land values emphasized this need, and resulted in the Bankruptcy Act of $1898 .^{28}$ This act, which is still in force, makes both voluntary and involuntary discharge more generally available. ${ }^{29}$ Its sixth section incorporates the exemption laws of the bankrupt's domiciliary state, but unlike its predecessors the current act provides no federal minimum. ${ }^{30}$

Although it is usually assumed that exemptions are important in enabling a debtor to begin a new financial life, the sixty-year old policy of incorporating state statutes into the Bankruptcy Act has never been fully reexamined. The recent growth of welfare legislation suggests that insolvents can be rehabilitated at the expense of the entire community, rather than by their creditors alone. ${ }^{31}$ The allowance of exemptions may severely injure general creditors; in over ninety per cent of all current individual bankruptcies, no

saries of such bankrupt as the said assignee shall designate and set apart, having reference in the amount to the family, condition, and circumstances of the bankrupt, but altogether not to exceed in value, in any case, the sum of five hundred dollars; and also the wearing apparel of such bankrupt, and that of his wife and children ... ; and such other property as now is, or hereafter shall be, exempted from attachment, or seizure, or levy on execution by the laws of the United States, and such other property not included in the foregoing exceptions as is exempted from levy and sale upon execution or other process or order of any court by the laws of the State in which the bankrupt has his domicile at the time of the commencement of the proceedings in bankruptcy, to an amount not exceeding that allowed by such State exemption laws in force in the year eighteen hundred and sixty-four ....

Bankruptcy Act of $1867, \S 14,14$ Stat. 522-23.

24. Bankruptcy Act of 1867, § 14, 14 Stat. 523.

25. See WARREN 112-14.

26. Id. at 110, 1.14-22.

27. Id. at 128-34.

28. Id. at 134-41; Poteat 8-9.

29. See Bankruptcy Act $\$ 4$.

30. See notes $11,16,23$ supra. Section 6 allows exemptions ". . . which are prescribed by the laws of the United States. ..." Under federal statutes, pensions, soldiers' bonuses, homesteads on federal land, railroad retirement benefits and soldiers' savings are exempt from levy or seizure. 1 ColsIER, BANKRUPTCY $\Uparrow 6.17$ (14th ed. Moore 1956) [hereinafter cited as COLLIER].

Incorporation of state exemptions does not violate the constitutional requirement that a bankruptcy act be "uniform." Hanover Nat'l Bank v. Moyses, 186 U.S. 181 (1902); see note 1 supra.

31. See Hanna \& Maclachlan, Cases on Creditors' Rights and Corporate REORganization 95 (5th ed. 1957). 
assets remain after exemptions for distribution to them. ${ }^{32}$ But even if the retention of exemptions is necessary, there are major flaws in the present system. Incorporation of state law engenders unwarranted diversity and often requires the application of legislation enacted without consideration of possible bankruptcy consequences. ${ }^{33}$ In addition, many state exemption provisions are hopelessly out of date, and the Bankruptcy Act itself, as judicially construed and sporadically amended, often emasculates their purposes. These factors suggest that the role of exemptions should be reevaluated. This Comment will first analyze state statutes. Thereafter, the problems of their incorporation in bankruptcy will be presented. Finally, the need for traditional exemptions will be considered in the light of welfare legislation, and methods of restructuring exemptions to meet contemporary requirements will be suggested.

\section{State Exemption Statutes}

Like early federal bankruptcy legislation, state exemption statutes were fashioned on an anvil of nineteenth century economics and politics. A narrative of the relevant history of three states-Georgia, Texas, and Connecticutwill serve to illustrate their development.

Georgia's economy was based on single-family agriculture throughout most of the nineteenth century. ${ }^{34}$ Her first exemption statute, enacted in 1822 , was designed to protect the small farmer through allowance of a few domestic necessities and tools of the trade to heads of families. ${ }^{35}$ When Congress failed to provide adequate national debtor relief after the depression of 1837 , Georgia, like many other states, created a homestead exemption, which placed

32. U.S. Adminnstrative OfFice of the U.S. Courts, Tables of Bankruptcy Statistics 2-3 (1957).

33. Virginia seems to be the only state which attempts to coordinate exemptions with bankruptcy.

VA. CODE ANN. § 34-17 (1950) provides:

The real or personal estate which a householder, his widow or minor children are entitled to hold as exempt may be set apart at any time before it is subjected by sale or otherwise..., provided that (1) any person who files a voluntary petition in bankruptcy may set it apart before or on the same day that he files his petition but not thereafter, or (2) any person against whom an involuntary petition in bankruptcy is filed may set it apart at any time before the expiration of the period after its adjudication within which he is required to file his schedules.

This statute is not an invalid interference with the Bankruptcy Act. In re Swift, $96 \mathrm{~F}$. Supp. 44 (W.D. Va. 1950).

34. Poteat 13-14.

35. "Whereas it does not comport with justice or expediency to deprive innocent and helpless women and children of a means of subsistence: . . . two beds and bedding, common bedsteads, a spinning-wheel, and two pair of cards, a loom, and cow and calf, common tools of his trade, and ordinary cooking utensils, and ten dollars' worth of provisions .. . [are exempt]." 1 NEw Dig. of LAws of GA. 385 (Cobb 1851). In 1834 the legislature, added the family Bible to this list. $1 \mathrm{id}$. at 388. 
twenty acres of land (plus five additional acres for each child) beyond the reach of a householder's creditors. ${ }^{36}$

The state was impoverished after the Civil War due to the collapse of confederate currency, emancipation, and successive crop failures. ${ }^{37}$ Very liberal exemptions were included in the post-bellum constitution in order to secure its ratification: a homestead up to $\$ 2,000$ in value and personal property not in excess of $\$ 1,000 .{ }^{38}$ The highest state court applied these exemptions retroactively to debts contracted prior to the constitution ${ }^{39}$ but was overruled by the Supreme Court. ${ }^{40}$ A constitutional convention in 1877 signaled the end of the carpetbagger regime. ${ }^{41}$ Destitute, the state required credit to finance further rehabilitation. ${ }^{42}$ Therefore, a constitutional provision reduced the value of exemptions and allowed partial waiver. Realty and/or personalty "to the value in the aggregate of sixteen-hundred dollars" became a householder's maximum exemption, and he could "waive or renounce in writing his right to the benefit of the exemptions . . . except as to wearing apparel and not exceeding three hundred dollars worth of household and kitchen furniture and provisions." 43 These provisions remain substantially unaltered today, although the constitution of 1945 granted the legislature power to prescribe laws relating to waiver of homestead. ${ }^{44}$

Unlike Georgia, Texas' exemptions have remained relatively rigid. The large homestead exemption of the 1845 constitution was probably a conscious effort to implement the policy of attracting new settlers ${ }^{45}$ and to counteract the supposed evils of a "credit" system. ${ }^{46}$ The 1876 constitution, reacting to pro-creditor carpetbagger rule, provided, as a check on northern lending interests, ${ }^{47}$ for an even more generous homestead exemption-200 acres of

36. This homestead was limited to "white citizens" and to qualify for the additional 5 acres, the child must be under fifteen. 1 id. at 389.

37. Poteat 17.

38. Ga. Const. art. VII (1868); see Poreat 17-18.

39. See Hardeman v. Downer, 39 Ga. 425 (1869).

40. Gunn v. Barry, 82 U.S. (15 Wall.) 610 (1872) (Georgia exemption violative of obligations of contracts clause as applied to debts contracted prior to its enactment).

41. See Poteat 20-21.

42. Ibid.

43. GA. Const. art. IX, § 1 (1877).

44. GA. Const. art IX (1945). The legislature, however, has continued the provision of the 1877 Constitution allowing waiver up to $\$ 300$. GA. CODE ANN. \$ 51-1101 (1937).

45. See Comment, 46 YaIE L.J. 1023, 1025-28 (1937). Other states have utilized exemptions as a means of encouraging immigration. Haskins, Homestead Exemptions, 63 Harv. L. Rev. 1289, 1290 (1950). See also Poteat 29; 2 Tex. Laws 35 (1838-1846) (allowing an immigrant head of a family to acquire 640 acres of land from the state by paying surveyor's fees).

46. Poteat 28-29.

47. Finty, Texas' Sacred Homestead Law, 10 Nat's Munic. Rev. 459 (1921) (purpose of the 1876 homestead provision was to "hog-tie the carpet baggers if they resumed control"). 
rural land of unlimited value and a city lot worth up to $\$ 5,000.48$ Further, most encumbrances upon the homestead were prohibited. ${ }^{49}$ These 1876 provisions remain in force today, despite criticisms that limitations on homestead mortgages unduly restrict credit. ${ }^{50}$

Creditor-oriented Connecticut ${ }^{51}$ stands in sharp contrast to both Texas and Georgia. In 1711 the colonial legislature enacted Connecticut's initial exemption law, which immunized a debtor's "apparel, bedding, tools, arms or implements of his household necessary for upholding life." "52 From time to time throughout the eighteenth and nineteenth centuries other specific items were cautiously added; but by 1882 the list of personal property exemptions reached virtually its present state. ${ }^{53}$ And the modest $\$ 1,000$ homestead exemption, finally enacted in $1885,^{54}$ was abolished in $1958 .^{55}$ Reflecting prevailing puritanical attitudes towards thrift and economic responsibility, the courts, through rigid construction, diminished the utility of even these exemptions. ${ }^{56}$

\section{The Antiquarianism and Variety of State Exemptions}

State laws exempting property from execution and sale, usually rooted in the nineteenth century, fail to aid the modern debtor. ${ }^{57}$ Presumably useful in a rural society, specific property exemptions have little relevance today when

48. TEx. Const. art. XVI, § 51. Improvements on both urban and rural property are exempt, and the city lot or lots are valued as of the time it was acquired as a homestead. The Texas constitution is unique in that it also provides for a "business" homestead. Rural or city property is thus exempt if it is used either for the "purposes of a home" or "as a place to exercise the calling or business of the head of a family." Texas courts have extended the exemption to all machinery annexed to the real estate. Willis v. Morris, 66 Tex. 628, 1 S.W. 799 (1886).

49. TEX. Const. art. XVI, $\S 50$. Encumbrances resulting from purchase money mortgages, taxes due, or improvements are allowed. Ibid.

50. See Schwulst, The Extension of Bank Crenit 32 (1927). See also Higgins v. Bordages, $88 \mathrm{Tex}, 458,31$. S.W. 52 (1895) (holding that an assessment for paving a sidewalk not a tax within the exception to the prohibition on encumbrances). See note 49 supra. As a result of this decision permanent street improvement in Texas cities was greatly retarded. Finty, stupra note 47 , at 460 .

51. See Davenport v. Lacon, 17 Conn. 278 (1848) ("The great principle regulating the intercourse of debtor and creditor in this state, has been that all of the property of the debtor should be responsible for the debts of the owner.") ; Enscoe v. Dunn, 44 Conn. 93 (1876).

52. See Conn. Acts \& Laws 1784, at 61, reenacting colonial laws.

53. Poteat 41-43.

54. Conn. Pub. Acts 1885, ch. 113, § 1 .

55. Conn. Pub. Acts 1958, ch. $27, \S 42$.

56. See, e.g., Hewitt v. McNerney, 73 Conn. 565 (1901) (refusing exemption of the implements of a spectacle maker as tools of the trade since defendant was a manufacturer and not retailer and therefore, not engaged in "trade"); Atwood v. DeForest, 19 Conn. 512 (1849).

57. See 11 N.Y. Judictal Councti Rep. 263 (1945); Hess, Homestead, Personal Property, and Wage Exemptions in Missouri and in other States, 12 Mo. L. REv. 21, 4146 (1947). 
wealth is measured by liquid assets, not acres, animals and artisans' tools. In Connecticut, for example, it would be rare to find an urban resident owning two tons of coal, two hundred pounds of wheat flour, two tons of hay, two cords of wood, five bushels of turnips or ten bushels of Indian corn. ${ }^{\text {.8 }}$ Similarly, exemptions for implements of the trade now have little utility, since few men work with their own tools. ${ }^{59}$ Moreover, many statutes operate unevenly, for legislatures have responded to particular interest groups by exempting specialized property such as ferryboats, newspaper presses, and molasses mills. ${ }^{60}$ The archaism of these statutes is accentuated by the general failure to effect an increase in value during recent periods of inflation. ${ }^{61} \mathrm{New}$ York and Maine, for example, defeat the original purpose of protecting the poor homeowner and his family by retaining a $\$ 1,000$ limit on homestead exemptions, and thereby permitting execution sale of virtually any homestead. ${ }^{62}$

58. See Conn. Gen. Stat. § 52-352 (1958).

59. See Glen, Fraudulent Conveyances 306 (rev. ed. 1940). Perhaps the most significant groups owning their own capital goods are lawyers, doctors, and other professionals. Most states provide that a professional man's library is exempt to a specified maximum value. E.g., Kan. Gen. Stat. Ann. \$ 60-3504 (1950); Minn. Stat. Ann. $\S 550.37$ (8) (Supp. 1958); Mo. Ann. Stat. $\$ 513.435(11)$ (1952); R.I. Gen. Laws ANN. \& 9-26-4(2) (1957).

60. See Tex. Rev. Civ. Stat. Ann. art. 3836 (1945) (ferryboat); Minn. Stat. Ann. $\$ 550.37$ (9) (Supp. 1958) (newspaper presses); WIs. Stat. AnN. $\$ 272.18(11)$ (1958) (printing presses); MIss. CODE ANN. $\$ 307(0)$ (1957) (molasses mill and equipment).

Other special-interest exemptions include: Cal. Civ. Proc. Code ANN. $\$ \$ 690.4$ (a physician's bicycie), 690.6 (miner's equipment), 690.8 (fishing boats and nets), 690.13 (nautical instruments) (1955); DEL. CODE ANN. tit. 10, $\$ 4902$ (1953) (a seamstress' sewing machine) ; Kan. Gen. Stat. Ann. \$ 60-3504 (1950) (spinning wheels); Me. Rev. Stat. Ann. ch. 112, $\$ 67(X)$ (1954) (same) ; Ore. Rev. Stat. $\$ 23.164$ (1957) (mobile house trailer); Wis. STAT. ANN. $\$ 272.18(13)$ (1958) (equipment of land title abstractor).

61. See MacLachlan, Bankruptcy 157 n.6 (1956) ; Haskins, supra note 45, at 1293. California is the outstanding exception to the general rule, having increased homestead exemptions twice in recent years to a current maximum of $\$ 12,500$. CaL. Crv. Code ANN. $\S 1260$ (1954). Alaska and Illinois have also recently enacted upward revisions of homestead exemptions. Alaska Comp. Laws ANn. $\$ 55-9-79$ (Supp. 1958) (from $\$ 2,500$ to $\$ 8,000$ in 1957) ; Irl. Rev. Stat. ch. $52, \S 1$ (1957) (from $\$ 1,000$ to $\$ 2,500$ in 1957).

62. N.Y. Civ. Prac. Act \$ 671; ME. Rev. Stat. Ann. ch. 112, § 69 (1954). The New York homestead exemption was first reexamined in 1945, sixty-nine years after its original incorporation into the Code of Civil Procedure. See 11 N.Y. Judictal CouncIL REP. 263 (1945). The Judicial Council refused to recommend an increase in value, believing that the public policy of the state favored a limited homestead. Id. at 269-70.

Thus, in many states, where the value of the property exceeds the exemption, the property may be sold and any proceeds above the maximum exemption used to satisfy creditors' claims. E.g., IxL. Rev. Stat. ch. 52, §§ 10-12 (1957) ; Mich. Stat. AnN. \$§ $27.1579-80$ (Supp. 1957) ; N.Y. Crv. PrAC. ACr $\$ \$ 676-77$. The Ohio statute, on the other hand, more fally protects the family home from forced sale. Where the value of the house and lot exceeds the exemption and cannot be divided without manifest injury or inconvenience the creditor is required, in lieu of sale, to accept all annual fair rental in excess 
Such antiquated statutes tempt courts to adapt exemptions to contemporary conditions by verbal manipulation. As a result, the interpretation of exemption legislation has been uneven, and, in some instances, bizarre. Despite the general rule that statutes in derogation of the common law receive strict construction, most courts have declared that exemptions should be liberally construed to accomplish their humanitarian and remedial purposes. ${ }^{63}$ Thus justified, some include automobiles under laws exempting "wagons"64 and allow expensive jewelry to escape liability for debts as "wearing apparel" or "tools of the trade." 65 Occasionally pianos qualify as "household furniture"; at other

of $\$ 100$, as determined by appraisers, until the debt, costs and interest are paid. Sale will be consummated only upon a failure by the debtor to meet the rental payments. OHIo Rev. Cope Ann. \$ 2329.78 (Page 1954); of. New Martinsville Grocery Co. v. Hannibal Store Co., 65 Ohio App. 50, 29 N.E.2d 226 (1940). See generally Haskins, supra note 45 , at $1312-15$.

63. See 1. Collier T 6.03, at 796; 2 Freearan, Executions 1062-64 (3d ed. 1900). Illustrative cases include In re Trotter, 97 F. Supp. 249 (W.D. La. 1951); Williams v. Swann, 220 Ark. 906, 251 S.W.2d 111 (1952); Shepard v. Findley, 204 Iowa 107, 214 N.W. 676 (1927) ; First Nat'l Bank v. Tiffany, 40 Wash. 2d 193, 242 P.2d 169 (1952). Some states have incorporated a rule of liberal construction into their statutes. E.g., TENn. Code Ann. \$26-216 (1955).

A few states, however, predominantly in the Northeast, cling to the rules of strict construction. E.g., Beierlein v. Faulkner, 15 N.J. Misc. 313, 190 Atl. 853 (Dist. Ct. 1937) ; Reinhart v. Gerhardt, 152 Pa. Super. 229, 31 A.2d 737 (1943).

64. E.g., Printz v. Shepard, 128 Kan. 210, 276 Pac. 811 (1929) ; McMullen v. Shields, 96 Mont. 191, 29 P.2d 652 (1934) ; Stichter v. Southwest Nat'l Bank, 258 S.W. 223 (Tex. Civ. App. 1924). Other jurisdictions, however, have given "wagon" a much more literal interpretation. E.g., In re McEuen, 19 F. Supp. 924 (W.D. Ky. 1937) ; Poznanovic v. Maki, 209 Minn. 379, 296 N.W. 415 (1941). As late as 1934, a New York court, although agreeing that a wagon was exempt as part of a "team," refused to include an automobile within the term on the ground that a vehicle, to be exempt, must be one to which a horse was ordinarily attached. Northern N.Y. Trust Co. v. Bano, 151 Misc. 684, 273 N.Y. Supp. 695 (Sup. Ct. 1934).

Some courts have exempted automobiles as "carriages," "buggies" and "vehicles." E.g., Patten v. Sturgeon, 214 Fed. 65 (Sth Cir. 1914); Hickman v. Hickman, 149 Tex. 439, 234 S.W.2d 410 (1950). See also Clark v. Vitz, 190 S.W.2d 736 (Tex. Civ. App. 1945) (house trailer placed on blocks outside owner's house and used as office, library and den not exempt as vehicle, but exemption allowed as part of homestead).

A few state statutes specifically exempt automobiles. See, e.g., Wade v. Rathbun, 23 Cal. App. 2d 758, 67 P.2d 765 (Dist. Ct. App. 1937) ; Youdan v. Kelley, 267 Mich. 616, 255 N.W. 342 (1934) (motor vehicle); White v. Corbett, 101 Mont. 1, 52 P.2d 156 (1935). Where a state statute specifically prohibits automobile exemptions or fails to mention them at all, exempt status may still be obtainable as a tool, implement or instrument necessary for a trade, profession or business. E.g., Pellish Bros. v. Cooper, 47 Wyo. 480, 38 P.2d 607 (1934); Gunn v. Credit Serv. Corp., 46 So. 2d 628 (La. Ct. App. 1950). But sec Law v. Simon, 110 Colo. 545, 136 P.2d 520 (1943).

65. E.g., Sellers v. Bell, 94 Fed. 801,812 (5th Cir. 1899) (wearing apparel); In re Richards, 64 F. Supp. 923 (S.D. Tex. 1946) (same); In re H. L. Evans \& Co., 158 Fed. 153 (D. Del. 1907) (same); In re Coller, 111 Fed. 503 (D. Mass. 1901) (watch exempt as tool of trade of cabinet-maker because it enabled him to keep true account of time he and other employers spent on jobs outside factory). Some statutes exempt specific items 
times they do not. ${ }^{66}$ Similarly, when the value limitations on a homestead are construed to exclude improvements, wealthier debtors receive a windfall because of heavy investment in their property. ${ }^{67}$ Liberalism, however, has not eliminated literalism. A generous exemption can be lost through noncompliance with technical procedures for claiming and describing exemptions. For example, a recent case denied a homestead exemption because of an incorrect statement of the number of the lot in question. ${ }^{68}$

In addition to problems created by quaint statutes painfully interpreted, a serious lack of uniformity exists among the states. The statutes run the gamut from sketchiness to specificity. ${ }^{69}$ Exemptions vary in amount from one hundred dollars worth of personal property plus wearing apparel and tools (but no homestead) in Maryland, ${ }^{70}$ to California's $\$ 12,500$ homestead exclusive of liens and encumbrances, and a substantial list of personal property items.71 Some states exempt liquid assets as well: earned wages and a small cash

of jewelry. E.g., ME. REv. STAT. ANN. ch. 112, $\$ 67$ (1954) (watch, wedding or engagement ring up to $\$ 10$ each). Most courts, however, have declined to extend protection to jewelry in the absence of express statutory language. E.g., Rivas v. Noble, 241 Fed. 673 (5th Cir. 1917); In re Everleth, 129 Fed. 620 (D. Vt. 1904); Towns v. Pratt, 33 N.H. 345, 349 (1856) ; Franzier v. Barnum, 19 N.J. Eq. 316 (ch. 1868).

66. Compare Cook v. Fuller, 35 Okla. 339, 130 Pac. 140 (1913) (piano exempt as household furniture) ; Kemp v. Swainsboro Ice \& Fuel Co., 47 Ga. App. 99, 169 S.E. 700 (1933) (same) ; and Alsup \& Thompson v. Jordan, 69 Tex. 300, 6 S.W. $\$ 31$ (18S7) (same), with Kehl v. Dunn, 102 Mich. 581, 61 N.W. 71 (1894) (piano not exempt as household furniture); Dunlap v. Edgerton, 30 Vt. 224 (1858) (same) ; Tanner v. Billings, 18 Wis. 163 (1864)'(same); and Ladker v. Gordon, 88 N.Y.S.2d 758 (App. T. 1949) (same).

Compare In re Tidball, 40 F.2d 560 (D. Wyo. 1930) (typewriter and phonograph not household furniture); and Dunbar v. Spratt-Snyder Co., 208 Iowa 490, 226 N.W. 22 (1929) (radio not exempt as musical instrument), with Brake v. Graham, 214 Ala. 10, 13, 106 So. 188 (1925) (piano and phonograph exempt to surviving spouse as household furniture); and In re Thompson, 15 Am. Bankr. R. (n.s.) 516 (Ref. D. Minn. 1929) (radio-phonograph combination exempt as furniture or musical instrument).

A recent case held that a television set did not qualify for exemption as household furniture or a musical instrument. Michaelson v. Elliott, 209 F.2d 625 (Sth Cir. 1954), affirming 113 F. Supp. 929 (D. Minn. 1953). But some states make television sets expressly exempt by statute. E.g., ORE. Rev. STAT. \$ 23.160(5) (1957).

67. See Haskins, supra note 45 , at $1292-93$ \& n.31.

68. Esten v. Cheek, 254 F.2d 667 (9th Cir. 1958). Although espousing the California rule of liberal construction of exemptions, the court denied a homestead exemption because the debtor filed "Lot 104" in his declaration but resided on "Lot 204." The declaration conformed in all other respects to the California statute. See also Lynch v. Stotler, 215 F.2d 776 (9th Cir. 1954) (declaration invalid for failure to state an estimate of cash value).

69. For examples of the more general statutes, see DeL. CoDE ANn. tit. 10, $\$ 4902$ (1953) ; Ill. Rev. STAT. ch. 52, \$§ 1, 13 (1957) ; MD. ANN. CoDE art. \$3, \$\$ 8, 11 (1957). For examples of detailed and specific statutes, see CaL. Crv. Proc. Code ANN. $\$ \$ 690$ 90.25 (1954); Tenn. Code Ann. \$§ 26-201, 26-301 (1955).

70. See Md. Ann. CoDE art. 83, \$\$ 8, 11 (1957).

71. CAl. Civ. Code ANN. $\$ 1260$ (1954) (homestead exemption; a person other than the head of a family is also entitled to a $\$ 5,000$ homestead); CAL. CIV. Proc. CODE ANn. 
allowance in lieu of specific property are fairly common, ${ }^{72}$ while California's provision for a thousand-dollar building-and-loan certificate represents the extreme of generosity. ${ }^{73}$ Rural acreage limits range from forty acres coupled with a maximum value, ${ }^{74}$ to Texas' 200 acre homestead of unlimited worth. ${ }^{75}$ Although variations are so great as to make generalizations dangerous, it is evident that western exemptions are greater than those of pro-creditor eastern jurisdictions. ${ }^{76}$ Regional economic differences may properly account for minor variations, but more outstanding disparities cannot be justified when tested by population shifts westward, industrialization of the south and the growing interrelationship of the national economy.

\section{The Diminished Utility of Exemptions}

Myriad legislative and judicial exceptions render exemptions even less valuable. While commonly defined as a right to hold property free from seizure

$\$ \$ 690-90.25$ (1954) (personal property exemptions). The listing of personal property items, exclusive of exceptions thereto and procedures for claiming, covers 26 sections in the code, and includes items such as washing machines, beehives, waiters' uniforms, entertainers' wardrobes, homestead association shares, and well drilling machinery as well as all the standard items.

72. See, e.g., Cal. Crv. Proc. Code Ann. $\$ 690.11$ (1954) (wages); Ill. Rev. Stat. ch. 62, 14 (1957). (same); Neb. Rev. Stat. ANn. $\$ 25-1558$ (1948) (same); Mass. ANN. LAws ch. $235, \S 34$ (1956) ( $\$ 20$ worth of shares in a co-operative association); MD. ANn. Cone art. 83, § 8 (1957) (money); N.D. REv. Cope $\$ \S 28-2203$, 28-2205 (1943) (same); Oнio Rev. CoDE Ans. $\$ \S 2329.62,2329.66$ (wages), 2329.81 ( $\$ 500$ in lieu of homestead) (Page 1953). See also Gray v. Putnam, 51 S.C. 97, 28 S.E. 149 (1897) (homestead exemption available in money).

73. See Cal. Civ. Proc. Code ANn. § 690.21. (1954). California also permits $\$ 1,000$ worth of homestead association shares to be held exempt if the debtor does not own a homestead. See Cal. Crv. Proc. Cone Ann. $\$ 690.12$ (1954).

74. E.g., Iowa Cone ANn. $\$ 561.2$ (1950) (40 acres, maximum value $\$ 500$ ); Mich. Stat. AnN. $\$ 27.1572$ (Supp. 1957) (40 acres, maximum value $\$ 2,500$ ).

Many states permit up to 160 acres to be held as a rural homestead, but provide a maximum value limitation. E.g., ALA. CODE ANN. tit. 7, § 625 (1940) (\$2,000 maximum); Alaska CoMrp. LAws ANN. $\$$ 55-9-79 (Supp. 1958) ( $\$ 8,000$ maximum; one-fourth acre in cities); LA. Const. art. $11, \S 1$ ( $\$ 4,000$ maximum) ; Mo. STAT. ANN. $\$ 513.475$ (1952) ( $\$ 1,500$ maximum); Orca. Const. art. $12, \S 1$; OrLa. Stat. Ann. tit. $31, \S 2$ (1955) ( $\$ 5,000$ maximum). Montana allows 320 acres of agricultural land to be held as a homestead, but the maximum value is $\$ 2,500$. Mons. Rev. Cone Ann. $\$ 33-124$ (1954).

Other states have various combinations of acreage and value limitations. See general1y National Ass'n of Credit Men, Credit Manual of Comantretal Laws 269-78 (1959) ; Haskins, supra note 45, at 1291-93; Hess, supra note 57, at 23-26.

75. Tex. Const. art. 16, § 51; Tex. Rev. Crv. Stat. Ann. art. 3833 (1945).

Several other states also have acreage limitations without providing for a maximum value. E.g., FLA. CoNst. art. 10, $\$ 1$ (160 acre rural; one-half acre in cities); MrNN. Stat. AnN. $\$ 510.02$ (1947) ( 80 acres); S.D. Code $\$ 51.1710$ (1939) (160 acres).

76. National Ass'N of CREDit MEN, op. cit. supra note 74, 269-78 (1959) (charts of state exemptions); Comment, 46 YALE L.J. 1023, 1031 (1937). The following jurisdictions, all located in the East, are the only ones which provide no homestead exemption at all: Connecticut, Delaware, Maryland, Pennsylvania, Rhode Island, and the District of Columbia. 
and sale under legal process for the payment of debts, ${ }^{77}$ an exemption does not extend to the claims of all creditors. Thus, in some states, a debtor is free to waive his right to an exemption, ${ }^{78}$ and creditors can therefore insist on waiver as a condition of a loan. In addition to consensual limitations, exemptions are usually statutorily circumscribed. To encourage home acquisition and improvement, homestead exemptions are often inapplicable against purchase-money lenders, mechanics and materialmen. ${ }^{79}$ Similarly, wage, ${ }^{80}$ tort, ${ }^{81}$ and tax claimants ${ }^{82}$ are often able to levy upon generally immune assets. Moreover, all property is available for the satisfaction of alimony and support obligations, since the family is the very group exemptions are designed to protect. $^{83}$

77. See, e.g., Clark v. Nirenbaum, \& F.2d 451, 452 (5th Cir. 1925), cert. denied, 270 U.S. 649 (1926) ; Poore v. Bowlin, 150 Tenn. 412, 414-15, 265 S.W. 671 (1924); Pickens v. Pickens, 125 Tex. 410, 414, 83 S.W.2d 951, 954 (1935) ; BLack, LaW Dictionary $681-82$ (4th ed. 1951).

78. See notes 221-22 infra and accompanying text.

79. E.g., CAL. CIv. CODE ANN. $\$ 1241$ (1954) (mechanics, materialmen and vendors liens); Ir. Rev. Stat. ch. 52, $\$ 3$ (1957) (purchase money and improvements); MinN. Const. art. $1, \S 12$ (construction, repairs and improvements); MrNn. Stat. ANn. $\$ \S$ 510.01 (repair and improvement), 510.05 (laborers and materialmen) (1946); N.Y. CIV. Prac. Act \& 671 (purchase money); OHIo Rev. Code AnN. \& 2329.72 (Page 1953); Wrs. Stat. ANr. $\$ 272.20$ (1957) (purchase money, mechanics and materialmen). See generally Haskins, stopra note 45 , at 1303-06.

Many states also provide that personal property exemptions shall be inapplicable against purchase money creditors. E.g., CAL. CIv. Proc. CODE ANN. $\$ 690.50$ (1954); Minn. Stat. Ann. $\$ 550.37$ (Supp. 1958); N.Y. Civ. Prac. Act $\$ 665(8)$; WIS. Stat. Ans. $\$ 272.18(30)$ (1957) ; Wyo. Conrp. Stat. ANn. $\$ 3-4510$ (1945) (purchase money exception extends to all exemptions).

80. E.g., Ill. Rev. Stat. ch. 52, 116 (1957) ; Minn. Const. art. 1, § 12; N.Y. Crv. Prac. Act $\$ 665(8)$.

81. See, e.g., IowA Cone $A_{N N} \S 627.7$ (1950) (no motor vehicle exempt from judgment for damages resulting from use on highway).

Courts have refused to allow exemptions against tort claims on the ground that statutes exempting property from liabilities for "debts" are not meant to include claims $e . x$ delicto within the meaning of "debt." E.g., Erlenbach v. Cox, 206 Ala. 298, 89 So. 465 (1921) ; Hill v. Bush, 192 Ark. 181, 90 S.W.2d 490 (1936) ; cf. Oakley v. Lasater, 172 N.C. 96,89 S.E. 1063 (1916). Contra, Smith v. Omans, 17 Wis. 395 (1863). See generally 2 FreEMAAN, ExeCUTIONS 1371-72 (3d ed. 1900); Note, 25 MrN. L. Rev. 66, 77$78(1940)$.

82. E.g., Ark. Const. art. 9, § 3; N.Y. Civ. Prac. Act $\$ 671$; Wis. Stat. Ann. $\S 272.20$ (1958). Contra, Cal. Crv. Proc. Code ANv. $\$ 690.27$ (1955) (tax debtor entitled to all personal property exemptions). Some states, however, provide that homesteads shall be exempt from real property taxation. See Haskins, supra note 45, at 130708; Newcomer, The Grozth of Property Tax Exemptions, 6 NAT'L TAX J. 116, 121-24 (1953) ; Comment, 46 Yale L.J. 1023, 1037-40 (1937).

83. E.g., In re Flanagan, 31 F. Supp. 402 (D.D.C. 1940); Commons v. Bragg, 183 Okla. 122, 80 P.2d 287 (1938); Gaskins v. Security-First Nat'1 Bank, 30 Cal. App. 2d 409, 86 P.2d 681 (Dist. Ct. App. 1939) ; Iowa Code Ann. $\$ \$ 627.11,627.12$ (1950). See Haskins, supra note 45 , at $1306-07$. 


\section{The Contracts Clause}

Another hindrance upon the efficacy of state exemptions comes from the federal constitution. State attempts at modernization or enlargement of exemptions are partially hampered by the prohibition against state impairment of contractual obligations. ${ }^{84}$ The Supreme Court, by declaring the means of enforcement available at the time of the loan a part of the debtor's repayment agreement, has disallowed exemptions enacted after the incurrence of the obligation. ${ }^{85}$ Under this doctrine; revision of exemption provisions may operate in futuro only, and cannot furnish debtor relief at times when it has been determined by legislatures to be most necessary. ${ }^{80}$ Indications exist, however, that in the context of economic crisis the impairment-of-contracts rule has been weakened. For example, during depression periods state legislatures have been permitted to declare mortgage moratoria, ${ }^{87}$ and to retroactively increase exemptions. ${ }^{88}$ While the Supreme Court decisions relaxing the strin-

84. U.S. Const. art. I, $\S 10$.

85. Gunn v. Barry, 82 U.S. (15 Wall.) 610 (1872) ; Edwards v. Kearzey, 96 U.S. 595 (1877) ; Bank of Minden v. Clement, 256 U.S. 126 (1921) ; Worthen Co. v. Thomas, 292 U.S. 426 (1934). State cases following the Supreme Court have also invalidated retrospective application of exemption increases. E.g., Herrington v. Godbee, $157 \mathrm{Ga} .343$, 121 S.E. 312 (1924) ; Daniel v. Thigpen, 194 La. 522, 194 So. 6 (1940) ; Rieger v. Wilson, 102 Mont. 86, 56 P.2d 176 (1936); see In re Rauer's Collection Co., 87 Cal. App. 2d 248, 196 P.2d 803 (Dist. Ct. App. 1948).

Although quite inconsistent with the rationale for voiding exemption increases, the impairment of contracts clause has not been applied to statutes which lessen or abrogate exemptions. But the cases do not explain why the borrower's contractual anticipation can be defeated. See Sparger v. Cumpton, 54 Ga. 355 (1875) ; Brearley School v. Ward, 201 N.Y. 358, 94 N.E. 1001 (1911) ; Laird v. Carton, 196 N.Y. 169, 89 N.E. 822 (1909); Leak v. Gay, 107 N.C. 468,12 S.E. 312 (1890); Chandler v. Horne, 23 Ohio App. 1, 154 N.E. 748 (1926).

Prior to Gunn v. Barry, supra, some state cases held that modifications of exemptions did not impair the obligations of pre-existing debts. E.g., Maxey, Gordan \& Co. v. Loyal, 38 Ga. 531 (1868) ; Mforse v. Goold, 11 N.Y. 281 (1854); Hill v. Kessier, 63 N.C. 437 (1869). The decisions were based on Chief Justice Taney's dictum in Bronson v. Kinzie, 42 U.S. (1. How.) 310, 315 (1843), to the effect that exemption changes are a question of remedy and do not impair the basic obligation to pay. The dictum was expressly repudiated in Edwards v. Kearzey, supra.

86. See In re Towers, 146 F. Supp. $8 \$ 2,885$ n.2 (N.D. Cal. 1956), aff'd sub nom. Tuwers v. Curry, 247 F.2d 738 (9th Cir. 1957); Comment, 1 Stan. L. REv. 350 (1949).

S7. Home Bldg. \& Loan Ass'n v. Blaisdell, 290 U.S. 398 (1934), 34 CoLum. L. REv. 361, 47 HaRv. L. REv. 660 . Subsequent cases further weakened the impairment-ofcontracts rule in favor of overriding state interests. Faitoute Iron \& Steel Co. v. Asbury Park, 316 U.S. 502 (1942) (upholding New Jersey Municipal Finance Act which adjusted claims of municipal creditors) ; Gelfert v. National City Bank, 313 U.S. 221 (1941) (upholding New York statute restricting amount of deficiency judgments); Honeyman v. Jacobs, 306 U.S. 539 (1939) (similar); Veix v. Sixth Ward Bldg. \& Loan Ass'n, 310 U.S. 32 (1940) (state may safeguard the solvency of building and loan associations in the public interest by restricting rights of certificate holders).

SS. In re Durband, \& F. Supp. 63 (N.D. Iowa 1934); cf. Folsom v. Asper, 25 Utah 299, 71 Pac. 315 (1903); Kirkman v. Bird, 22 Utah 100, 61 Pac. 338 (1900). The Utah 
gency of the contracts clause involved emergencies resulting from the depression of the 1930's, post hoc alteration of creditors' rights in inflationary periods-less catastrophic but more devastating to the debtor who relies upon his exempt property-could be similarly justified. The problem may be viewed as one of balancing the policy of safeguarding debtors from inflation's erosive effects against that of protecting creditors' expectations. If the state's determination is reasonably limited and suitably framed to effectuate the former, the obligations-of-contracts clause should be satisfied. ${ }^{89}$

\section{Limitations on Exemptions Due to Conflict of Lazes}

Beyond the difficulties encountered in modernization, a state may find its policy of protecting debtors through exemptions frustrated by unfortunate conflict of laws precedents. In this area, the Supreme Court (in contradistinction to its view when dealing with the contracts clause) regards exemption statutes as affecting remedy only. Therefore, they are considered procedural for conflicts purposes, ${ }^{90}$ and thus not applied in a foreign forum. Consequently, a creditor can escape the exemption statute of the state in which the obligation was incurred, and in which both parties reside, by suing his debtor in another jurisdiction. ${ }^{91}$ This can be easily accomplished by assigning the claim to a third party outside the state. Since exemptions normally apply only to residents, ${ }^{92}$ the protection of the forum will also be

court, prior to Blaisdell, supra note 87, refused to follow Edwards v. Kearzey, 96 U.S. 595 (1877), and upheld retrospective application of exemptions on grounds of necessity. But see Worthen Co. v. Thomas, 292 U.S. 426 (1934) (exemption increase fails since legislation was not limited to the emergency upon which legislature sought to justify enactment) ; In re Fox, 16 F. Supp. 320 (S.D. Cal. 1936).

The Supreme Court has indicated an unwillingness to look behind a state declaration of an overriding policy necessitating retroactive alteration of creditors' rights. See East N.Y. Sav. Bank v. Hahn, 326 U.S. 230, 232-33 (1945). Therefore the constitutional proscription can be avoided by "temporarily" raising exemptions, and continually passing extensions. Once sufficient time has elapsed, and all outstanding contracts were entered into during the period of the increased exemption, the legislation can be made permanent. Re-enactments of remedial legislation after frequent reconsiderations were impliedly approved in the New York mortgage moratory legislation. East N.Y. Sav. Bank v. Hahn, supra at 233-35. Giving permanent status to the periodic extensions would then be much easier, for repeal might result " in an emergency more acute than that which the original legislation was intended to alleviate." N.Y. LEGIS. Doc. No. 45, 165th Sess. 25 (1942), cited in East N.Y. Sav. Bank v. Hahn, supra at 235.

89. This argument is more elaborately presented in Comment, 1 STAN. L. Rev. 350 (1949).

90. See Chicago, R.I. \& Pac. R.R. v. Sturm, 174 U.S. 710 (1899) ; Baumgardner v. Southern Pac. Co., 177 S.W.2d 317 (Tex. Civ. App. 1943) ; 3 Beale, Conflicts of Laws 1616 (1935).

91. See Boykin v. Edwards, 21 Ala. 261 (1852); Kyle \& Co. v. Montgomery, 73 Ga. 337 (1884); American Central Ins. Co. v. Hettler, 46 I11. App. 416 (1892).

92. See, e.g., Minn. Stat. Ann. \$ 550.37(18) (1947) ; Mont. Rev. Code Anv. § 935813 (1947) ; Neb. Rev. Stat. ANw. § 25-1556 (1948). Even where statutes are silent 
denied and the debtor deprived of the benefit of any exemption. ${ }^{93}$ The garnishment remedy makes evasion of local exemptions more readily available. ${ }^{94}$ Since an obligor may be garnished wherever his obligee could have sued him, creditors can defeat an exemption by garnishing in a foreign jurisdiction. ${ }^{95}$ Wage exemptions are particularly subject to such subversion, for corporate employers can be sued in any state where they are "doing business."

Although some states have attempted to prevent such facile avoidance of exemptions, their efforts are exceptional, and, even when available, of limited use. A few states make the assignment of a claim for the purpose of escaping local exemptions a criminal offense, ${ }^{97}$ and several give the debtor a damage action against the assignor-creditor ${ }^{98}$ Some state tribunals will enjoin a creditor from proceeding with a foreign suit which will evade local exemption statutes ${ }^{90}$ but personal jurisdiction over the creditor is necessary, and, if the creditor is willing to risk a contempt action upon his return to the enjoining

as to the applicability of exemptions, non-residents may not qualify. Boykin v. Edwards, 21 Ala. 261 (1852); Mignogna v. Chiaffarelli, 151 Mo. App. 359, 131 S.W. 769 (1910). But see Menzie v. Kelly, 8 Ill. App. 259 (1881.).

93. See Mooney v. Union Pac. R.R., 60 Iowa 346, 14 N.W. 343 (1882) ; Ferneau v. Armour \& Co., 303 S.W.2d 161 (Mo. Ct. App. 1957).

94. See Harris v. Balk, 198 U.S. 215 (1905) (judgment against garnishee in foreign state entitled to full faith and credit in subsequent action by principal debtor even though the principal debtor was not served).

The Harris case settled the rule that a debt may be garnished in any state where personal jurisdiction over the secondary debtor is obtained. Thus, the debt is located wherever the garnishee may travel, if an individual, or be served, if a corporation. This rule has been criticized for making the garnishee vulnerable to spurious claims in remote jurisdictions. See Beale, The Exercise of Jurisdiction in Rem to Compel Paynent of a Dcbt, 27 HaRv. L. REv. 107, 121. (1913). But courts have gone far in allowing such actions. See, e.g., Pierce v. Pierce, 153 Ore. 248, 56 P.2d 336 (1936) (debt due Nebraska resident from New York corporation may be garnished in Oregon where corporation had filed consent to service).

95. Lyon \& Co. v. Callopy, 87 Iowa 567, 54 N.W. 476 (1893) ; Burlington \& M.R.R. v. Thompson, 31 Kan. 180, 1 Pac. 622 (1884) ; Bingenheimer Mercantile Co. v. Weber, 49 N.D. 312, 191. N.W. 620 (1922).

96. See cases cited note 95 supra.

97. See, e.g., GA. CoDE ANN. $\S \S 46-209,46-9901$ (1937) (each assignment a misdemeanor punishable by a fine of not less than $\$ 10.00$ and not more than $\$ 50.00$ ); IND. Stat. Ann. \$ 10-4904 (1956); Ill. Rev. Stat. ch. 52, \$\$ 19, 20 (1957).

98. E.g., GA. CoDE ANN. $\$ 46-210$ (1937) (authorizing suit against either the assignor or assignee to recover the amount garnished, costs and damages sustained including those resulting from loss of employment, discharge or suspension of work); IND. STAT. ANN. \$10-4904 (1956). In addition to providing a civil remedy for recovery of exemptions defeated by an out of state proceeding, Maryland law provides that all the property of the defendant-creditor shall be subject to execution to satisfy the plaintiffdebtor's judgment. Mid. ANN. Code art. 83, § 15 (1956).

99. See Allen v. Buchanan, 97 Ala. 399, 11 So. 777 (1892); Wierse v. Thomas, 145 N.C. 261,59 S.E. 58 (1907) ; Moton \& Son v. Hull, 77 Tex. 80,13 S.W. 849 (1890); cf. Cole v. Cunningham, 133 U.S. 107 (1890) (not a violation of full faith and credit for a state to enjoin one of its citizens from executing on property in another state). 
state, the foreign court is free to proceed and may well ignore the injunction. ${ }^{100}$ More significantly, the foreign action may have reached judgment before the debtor is aware of it and can take defensive steps. ${ }^{101}$ And if the suit is instituted by garnishment, the resulting lien creates a "superior equity," entitled to recognition in other states, and thus precludes an effective injunction as soon as it attaches. ${ }^{102}$ Only on rare occasions have courts protected an out-ofstate debtor by invoking the discretionary principle of comity and applying the exemptions in force in the debtor's domicile, ${ }^{103}$ or by refusing to entertain the proceeding if the creditor's evident purpose is the avoidance of another jurisdiction's statutes. ${ }^{104}$

The accordance of full faith and credit to foreign exemption statutes would protect the debtor regardless of the locus of the suit. The Constitution requires states to give the public acts of a foreign state the same effect they have at home. ${ }^{105}$ This aspect of the full faith and credit clause has been long dormant, but recent decisions indicate a new vitality. Thus state courts are required to enforce statutory causes of action created by other jurisdictions where none exists in the forum state as long as her citizens enjoy similar rights and she has no public policy against such suits. ${ }^{106}$ Although exemptions

100. Union Pac. R.R. v. Rule, 155 Minn. 302, 193 N.W. 161 (1923) (full faith and credit need not be accorded foreign injunction against prosecuting a suit in forum); cf. Fall v. Eastin, 215 U.S. 1 (1909). But cf. Michigan Trust Co. v. Ferry, 228 U.S. 346 (1912). See also Messner, The Jurisdiction of A Court of Equity over Persons To Compel the Doing of Acts Outside the Territorial Limits of the State, 14 MINN. L. REv. 494, 497, 505 (1930) (concluding that these cases suggest that an injunction by a foreign court against proceedings in the forum state need not be granted full faith and credit unless the forum itself would have granted an injunction under the facts disclosed).

101. Harris v. Balk, 198 U.S. 215 (1905), requires that the garnishee, in order to protect himself from double liability, notify the debtor of the pending garnishment proceedings. While such notification may enable the debtor to appear and defend, it places an expensive burden upon him to travel out of state to protect his rights. See Holt, The Federal Interpleader Act and Confict of Laws in Garnishment, 4 U. CHI. L. Rev. 403, 408 (1937). If service on the principal debtor is only made by publication and he fails to appear, the garnishee to avoid a second liability to the debtor, must have raised the defense that the property was exempt in the garnishment action. See In re Beals, 116 Fed. 530 (D. Ind. 1902).

102. Sanders v. Armour Fertilizer Works, 292 U.S. 190, 204 (1934).

103. Schroeder Wine \& Liquor Co. v. Willis Coal \& Mining Co., 179 Mo. App. 93, 161 S.W. 352 (1913) ; Strawn Mercantile Co. v. First Nat'1 Bank, 279 S.W. 473 (Tex. Civ. App. 1925).

104. See Drake v. Lake Shore \& M.S. Ry., 69 Mich. 168, 37 N.W. 70 (188S) (where principal debtor, his creditor and garnishee all resided in Indiana, and all claims arose there, Michigan forum refused to lend itself to the evasion of Indiana's laws). See also ILL. REv. StAT. ch. 52, § 21. (1957) (requiring application of the wage exemption laws of a debtor's residence to garnishment in Illinois if the wages were earned outside of Illinois).

105. U.S. Const. art. IV, $\S 1$.

106. First Nat'1 Bank v. United Air Lines, Inc., 342 U.S. 396 (1952) (Illinois may not bar an action under the Utah wrongful death act even though the Illinois wrongful death act only extended to deaths within the state); Hughes v. Fetter, 341 U.S. 609 (1951) (Wisconsin required to apply Illinois wrongful death statute). 
vary widely in character and amount, few if any states could claim that a sister state's exemption violates her public policy. While states are not required to enforce each others "procedural" statutes, ${ }^{107}$ the traditional classification of exemptions as "procedural" for conflicts purposes is inappropriate. The justification for nonapplication of "procedural" statutes-administrative convenience ${ }^{108}$-is unpersuasive in the context of exemptions, which could be easily applied by a foreign jurisdiction and create expectations similar to so-called "substantive" rights. ${ }^{109}$ Therefore the Supreme Court should require that they be given full faith and credit.

\section{State Exenptions in Bankruptcy}

\section{Jurisdiction of the Bankruptcy Court over Exempt Property}

Section 6 of the Bankruptcy Act incorporates state exemptions by providing: "This Act shall not affect the allowance to bankrupts of the exemptions which are prescribed by the laws of the United States or by the State laws in force at the time of the filing of the petition in the State wherein they have had their domicile ...."

While bankruptcy courts must follow state law in determining what is exempt, ${ }^{110}$ federal bankruptcy law regulates the procedure by which exemptions are claimed and exempt property set apart for the debtor. ${ }^{111} \mathrm{~A}$ bankrupt is required to surrender all of his assets-both exempt and non-exempt-to the trustee in bankruptcy. He then must petition for the return of any items which he contends are not subject to the trustee's claims. ${ }^{112}$ Failure to claim an exemption within a reasonable time after the petition is filed constitutes a general waiver. ${ }^{113}$ The trustee is empowered to determine tentatively what

107. 3 BeAle, Conflict of Laws 1600 (1935).

108. See Cook, "Substance" and "Procedure" in the Conflict of Lazws, 42 YALE L.J. 333 (1933). See also Note, 47 Harv. L. Rev. 315 (1933).

109. Exemption laws are treated as substantive for purposes of the obligations of contract clause of the Constitution. See notes 84-85 supra and accompanying text.

110. See Dixon v. Koplar, 102 F.2d 295 (8th Cir. 1939) ; Arbogast v. Gottfried, 58 F.2d 156 (6th Cir. 1932) ; In re Baker, 182 Fed. 392 (6th Cir. 1910) (where state court has announced a reasonably clear rule as to a particular statute, bankruptcy court is not justified in disregarding it on belief that the state court may later change rule). But cf. In re Sullivan, 148 Fed. 815 (8th Cir. 1906) (bankruptcy court not bound to follow mere dictum of state court as to construction of state's exemption statute). See generally 1 COLLIER $\llbracket 6.03$.

111. In re Friedrich, 100 Fed. 284 (7th Cir. 1900) ; In re Van Allsburg, 14 F.2d 672 (W.D. Mich. 1926). But see In re Wunder, 133 Fed. 821 (E.D. Pa. 1905).

112. Bankruptcy Act $\S 7 \mathrm{a}(8)$ requires the bankrupt to claim exemptions in the schedules filed in the bankruptcy proceedings. The schedule claiming exemptions, B-5, must be filed with the petition if a voluntary proceeding or within 5 days after adjudication if involuntary. 1 CollIer If 6.19. But see In re French, 231 Fed. 255 (W.D. N.Y. 1916) (exemptions self-executing and there is no necessity for claiming them).

113. In re Gunzberger, 268 Fed. 673 (M.D. Pa. 1920) ; In re Gerber, 186 Fed. 693 (9th Cir. 1911); Moran v. King, 111 Fed. 730 (4th Cir. 1901). See also 1 Collier If 6.19. 
exemptions, if any, are allowable but his findings must be approved in court ${ }^{114}$ where the bankrupt or any individual creditor may contest his decision. ${ }^{110}$ Upon final approval, the trustee returns exempt assets to the debtor. Under Lockwood $v$. Exchange Bank, ${ }^{116}$ title to exempt property remains in the debtor, and the bankruptcy court's jurisdiction over such assets extends only to the determination of the exemption's validity. ${ }^{117}$

Since the court is thus powerless to adjudicate conflicting interests in exempt property, ${ }^{118}$ a creditor who has a valid lien upon property which is generally exempt will be remitted to a state court to foreclose it.119 In cases in which the creditor has no lien, but under state law may levy on generally immune assets, he will lose his right to pursue them if the bankrupt is discharged before a lien is obtained in a state court. ${ }^{120}$ In order to protect a creditor in this predicament the Supreme Court held in Lockwood that the bankruptcy court should delay discharge for a reasonable period.121 But this does not completely protect the creditor, since the undischarged debtor may still dissipate or damage the asset before perfection. ${ }^{122}$ To avoid such conse-

114. Bankruptcy Act $\S 47 a(6)$.

115. General Order 17 allows 10 days after the trustee files his report for such objection, unless further time is granted by the court. 11 U.S.C. order 17 (1952).

116. 190 U.S. 294 (1903).

117. Ibid. In Lockwood a creditor held a promissory note containing a written waiver of the debtor's homestead exemption in a state which sanctioned waivers. The creditor petitioned the bankruptcy court to set such portion of the exempt property aside to him as necessary to satisfy his claim. The Supreme Court held that the petition should be denied for lack of jurisdiction over exempt property, since such questions were for the determination of the state court. See generally 1 Collier $\llbracket 6.05$; Friebolin, Peculiar Nature of Homestead Exemption: Their Disposition in Bankruptcy, 18 U. CINc. L. Rev. 146 (1949).

118. See note 117 supra; Novak v. O'Neal, 201 F.2d 227 (5th Cir. 1953); Woodruff v. Cheeves, 105 Fed. 601 (5th Cir. 1901); Note, 32 Texas L. Rev. 222 (1953); Nadler, Recent Developments in Bankruptcy, 27 REF. J. 121 (1953).

119. Duffy v. Tegeler, 19 F.2d 305 (8th Cir. 1927); In re Rabb, 21 F.2d 254 (N.D. Tex. 1927); In re Vonhee, 238 Fed. 422, 428 (W.D. Wash. 1916); cf. Zapalac v. White, 9 F. Supp. 419 (S.D. Tex. 1934). But cf. In re Gordon, 115 Fed. 445 (D. Vt. 1902) (bankruptcy court has jurisdiction to adjudicate claims which pre-existed the acquisition of the homestead since under state law the property was not exempt as to such claims).

120. Blake v. Alswager, 55 N.D. 776, 215 N.W. 549 (1927).

121. The meaning of "a reasonable period" in this context has never been litigated. The 1938 amendment to Bankruptcy Act $\$ 14(\mathrm{~b})$, providing for automatic discharge in the absence of timely objection, does not appear to have considered the Lockwood rule. 3 Renington, Bankrouptcy \& 1317 (rev. ed. 1957) [hereinafter cited as ReMrngton].

The bankruptcy court will not interfere with the efforts of creditors to perfect their claims against exempt property in the state court. In re Bittle, 239 Fed. 191 (E.D. Pa. 1917). But see Bracewell v. Hughes, 214 Iowa 241, 242 N.W. 66 (1932) (unsecured creditor cannot maintain a suit in a state court during the pendency of the bankruptcy proceedings for the purpose of creating a lien but can only enforce a lien if one exists) (dictum).

122. See In re Burden, 83 F. Supp. 416, 420 (D. Neb. 1949) (exempt truck damaged after being set off to the bankrupt). 
quences some bankruptcy courts will order the trustee to retain temporary possession of the property. ${ }^{123}$ In addition, exempt property in the hands of the trustee may be attached by the creditor ${ }^{124}$ or impounded by a state receiver until a lien is established. ${ }^{125}$

The Lockwood doctrine is unnecessarily injurious to the bankrupt. The delay involved in postponing discharge and retaining judicial control pending state-court litigation can seriously jeopardize his ability to support and rehabilitate himself by withholding property to which he is entitled. ${ }^{126}$ The creditor's suit may fail; and, in situations in which the debtor retains rights in a portion of the property, his equity will be inaccessable until judicial sale of the asset. Both parties are of course inconvenienced by the added expense of a second litigation in another forum. ${ }^{127}$ If the bankruptcy court were to adjudicate all claims in exempt property and return to the debtor only those assets which are totally immune to creditors, these difficulties would be avoided. Once possessed of the property, it can expedite the litigation through summary proceedings. ${ }^{128}$ Furthermore, the bankruptcy docket is generally less crowded. ${ }^{129}$ There are no policy objections to overruling Lockwood nor would this course be entirely unprecedented. Bankruptcy courts frequently adjudicate claims in property in which general creditors have no interest. ${ }^{130}$ Moreover, instances may be found in which the bankruptcy court currently administers exempt property. If the property's value exceeds the state dollar limit, the

123. Where the exempt property is a fund of money in the hands of the trustee, the court will order its retention to protect creditors. In re J. E. Maynard \& Co., 183 Fed. 823 (N.D. Ga. 1910) ; In re Castleberry, 143 Fed. 1018 (N.D. Ga. 1905).

124. See Hukill-Hunter Co. v. Oliver, 43 F.2d 100 (3d Cir. 1930); B. F. Roden Grocery Co. v. Bacon, 133 Fed. 515 (5th Cir. 1904); Dickens v. Breedlove, 34 Ga. App. 459 , 129 S.E. 886 (1925).

125. See In re Meredith, 144 Fed. 230 (N.D. Ga. 1906) ; Bell v. Dawson Grocery Co., 120 Ga. 628, 48 S.E. 150 (1904).

126. See, e.g., In re Urban, 136 F.2d 296 (7th Cir. 1943) ; Charnesky v. Urban, 245 Wis. 268, 14 N.W.2d 161 (1944) (ten months elapsed before title to an exempt car was determined in a state court).

127. Cf. Stein v. Bostian, 133 F.2d 586, 589 (8th Cir. 1943) (requiring the enforcement of tax claims on exempt property in state court despite recognition that it would be more "convenient, expeditious and economical" to adjudicate such claims in bankruptcy); Leiter v. Steinback, 184 F.2d 751, 754 (5th Cir. 1950) (concurring opinion) (suggesting remission to state court for adjudication only when issue is complicated).

128. Possession is the basis of bankruptcy courts' summary jurisdiction. Thompson v. Magnolia Petroleum Co., 309 U.S. 478, 481 (1940). Since the trustee has possession of exempt property, no reason appears, aside from Lockwood, for refusing summary jurisdiction in this, as in many other phases, of a bankruptcy proceeding. See 1 CoLrIER If 6.06 , at 814 n.11. Moreover, summary jurisdiction is often allowed although it is in most instances not specifically conferred by the act. See $2 i d$. $\{23.04$.

129. See Moore, Cases on Debtors' and CReditors' Rigerts 484-85 (1955).

130. Where, for example, the debtor's realty is subject to several security interests, the court may sell the property, deduct the applicable costs, and distribute the proceeds to the proper claimants. Goggin v. Division of Labor Law Enforcement, 336 U.S. 118, 130 (1949) ; Van Huffel v. Harkelrode, 284 U.S. 225 (1931); see 6 Rearington § 2583. 
court will sell the property and apportion the proceeds between the estate and the bankrupt. ${ }^{131}$ Finally, bankruptcy determination of all exempt-property issues would not harm other creditors, since the applicable costs could be taxed to the debtor and the litigating creditor. ${ }^{132}$

\section{Interpretation of Section 6}

\section{The Definition of "Exempt"}

Although section 6 provides that the Bankruptcy Act "shall not affect the allowance of exemptions . . . which are prescribed by the laws of the [states]," the act makes no effort to delineate what is an exemption under state law. Furthermore, local law has no occasion to classify property in which creditors' rights are restricted as "exempt" or "nonexempt," since normally the only issue in state court is simply whether a particular creditor can reach the asset in question. Nor do codifications of state statutes provide workable criteria, since not all state legislation removing property from liability for the payment of debts appears in sections labeled "exemptions." 133 A cognate problem arises from state holdings that certain intangible rights are not subject to levy and execution because they are not "property," since the question of whether or not such immunity constitutes an "exemption" goes unasked and unanswered. ${ }^{134}$ These intangibles are generally freely transferable, and title

131. First Nat'1 Bank v. Lanz, 202 Fed. 117 (5th Cir. 1913) ; see Bank of Nez Perce v. Pinde1, 193 Fed. 917 (9th Cir. 1912) (where bankrupt's exempt and nonexempt property are inseparable court may sell the property and allot exemption from proceeds of sale); In re Miller, 95 F.2d 441 (7th Cir. 1938) (same). If the bankrupt prefers his exemption in cash rather than property, he may consent to sale by the bankruptcy court. In re Cunningham, 15 F.2d 700 (E.D.S.C. 1926). When a debtor elects to have the court sell exempt assets, the bankrupt only receives the amount produced by the assets on sale. In re Moore, 274 Fed. 645 (E.D. Mich. 1921.).

Generally, when exempt property is sold the bankrupt must bear his proportional share of the selling costs. In re Kane, 127 Fed. 552 (7th Cir. 1904). But see In re Hopkins, 103 Fed. 781 (D. Vt. 1930) (trustee and not bankrupt must pay for expenses of sale where exempt and nonexempt property are inseparable and must be sold).

132. See cases cited note 130 supra.

133. E.g., Ilz. REv. Stat. ch. $22, \S 49$ (1958), dealing with supplementary procedures to discover assets of a defendant against whom a judgment has been returned unsatisfied. The section provides inter alia that a trust corpus established by a third party is not subject to execution. See Knight v. Gregory, 389 Ill. 554, 60 N.E.2d 399 (1945) ( $\$ 49$ does not create an "exemption"); 1950 U. ILL. L.F. 269 (federal courts would be bound if state classified this interest as an exemption).

See DeL. CoDE ANv. tit. 12, $\S 3536$ (1953) (immunity of trust appears in section dealing with trusts); W. VA. CODE ANN. $\$ 3538$ (1955) (same). See generally 2 Scort, TRUSTS $\$ 152.1$ (1956).

134. See Barclay v. Smith, 107 Ill. 349 (1883) (membership in the Chicago Board of Trade not "property" and therefore not subject to judicial process); Thompson v. Adams, $93 \mathrm{~Pa} .55$ (1879) (seat on Philadelphia Board of Brokers); Pancoast v. Gowen, $93 \mathrm{~Pa} .66$ (1879) (seat on Philadelphia stock exchange). See also Preston v. Ryan, 45 Mich. 174, 7 N.W. 819 (1881) (equity of redemption not liable to seizure); Garber 
to them will therefore pass to the trustee unless the state-granted freedom from creditors qualifies as an "exemption." 135

Bankruptcy courts avoid these definitional problems by ignoring the possibility that other local provisions for immunity from creditors could be an exemption, ${ }^{136}$ or reach the same result more frankly by specifically holding that for bankruptcy purposes an exemption must be so denominated by the state. ${ }^{137}$ While these precedents provide a simple standard, it is by no means clear that Congress intended operation of section 6 to be dependent solely upon the language of the state legislatures. This ambiguity could be resolved by legislative action on both federal and state levels. The Bankruptcy Act could equate "exempt" property with property which under state law is not subject to levy or execution sale by a general creditor. This, however, could potentially result in the exemption of large and valuable assets which the state legislature never intended to be exempt in bankruptcy. For example, some statutes provide only a temporary immunity from creditors' process, allowing execution after an elapsed time or the occurrence of some condition. ${ }^{138}$ Under

v. Bankers' Mortgage Co., 27 F.2d 609 (D. Kan. 1928) (equity of redemption immune under state law but not "exempt" in bankruptcy).

Under state law other property outside the traditional classification of exemptions is immune from creditor's process. See, e.g., In re Kearns, 8 F.2d 437 (4th Cir. 1925) (since tenancy by the entirety not subject to creditors of one spouse or transferable without consent of the other spouse, it does not pass to trustee). The Kearns court equated tenancy by the entirety to an exemption. Id. at 439 (dictum).

135. Bankruptcy Act $\S 70$ (a) provides:

The trustee... shall ... be vested by operation of law with the title of the bankrupt as of the date of the filing of the petition . . except . . as . . to property which is held to be exempt, to all ... (5) property, including rights of action, which prior to the filing of the petition he could by any means have transferred or which might have been levied upon and sold under judicial process against him, or otherwise seized ....

136. In several cases, property, although immune from creditors' process, was found to pass to the trustee in bankruptcy under $\$ 70$ (a) (5) because it was voluntarily alienable under state law, the court never discussing whether the local immunity constituted an exemption. Board of Trade v. Johnson, 264 U.S. 1 (1924) (membership in board of trade) (dictum); Young v. Handwork, 179 F.2d 70 (7th Cir. 1949) (equitable life interest in trust); Pollak v. Meyer Bros. Drug Co., 233 Fed. 861 (8th Cir. 1916) (vested remainder in a trust) ; Fisher v. Cushman, 103 Fed. 860 (1st Cir. 1900) (liquor license); In re Evans, 235 Fed. 956 (D. Idaho 1916) (right of entry) ; Patrick v. Beatty, 202 N.C. 454, 163 S.E. 572 (1932) (trust of real estate).

137. See Page v. Edmunds, 187 U.S. 596 (1903) (stock exchange seat); Garber v. Bankers' Mortgage Co., 27 F.2d 609 (D. Kan. 1928) (equity of redemption); In re T. C. Burnett \& Co., 201 Fed. 162 (E.D. Tenn. 1912) (growing crops).

138. Under Kansas law, for instance, a debtor's equity of redemption is immune from creditors. Kan. Gen. Stat. Ann. $\$ 60-3455$ (1949). But the right to redeem only lasts for eighteen months after the mortgage is foreclosed. KAN. GEN. STAr. ANn. § 60-3439 (1949); see Garber v. Bankers' Mortgage Co., 27 Fed. 609 (D. Kan. 1928) (refusing to hold Kansas equity of redemption to be exempt). Contra, Jones v. Wakeeney State Bank, 100 F.2d 879 (10th Cir. 1939) (not citing Garber). 
state law the creditor's right to resort to such property is only postponed, but incorporation of these laws into bankruptcy would give the debtor total immunity since later execution would be precluded by discharge. However, state legislatures could specifically provide which immunities shall not apply in bankruptcy. ${ }^{139}$

\section{Obtaining an Exemption on the Eve of Bankruptcy}

Since exemptions are typically framed in terms of specific property a debtor is tempted to convert his nonexempt tangibles and his liquid wealth into items within state exemption provisions on the eve of bankruptcy. ${ }^{140}$ Once discharged, he can reconvert his newly acquired mule or molasses mill into cash. Many states permit such conduct, holding that while "fraud" will de-immunize otherwise exempt property, a purchase during insolvency for the sole purpose of obtaining an exemption is not "fraudulent."141 They reason that the statutory language is absolute, ${ }^{142}$ that exemptions ought to be liberally construed, ${ }^{143}$ and that unsecured creditors, presumptively aware of the possibility of conversion, can not be found to have detrimentally relied upon any particular nonexempt property. ${ }^{144}$ As might be expected, other states hold that the transmutation of nonexempt assets into exempt property either while insolvent or with intent to defraud creditors, or both, estops the debtor from successfully insulating the item from creditors' claims. ${ }^{145}$

Since section 6 incorporates only those exemptions allowed by state law, the bankruptcy courts follow the local rule in determining the effect of acquiring exempt property shortly before bankruptcy. ${ }^{146}$ Aside from adding still more diversity to the Joseph's coat of bankruptcy exemptions, this doctrine is difficult to apply since the state cases furnish unprofitable precedents-each normally turns on its own facts. ${ }^{147}$ Furthermore, policy considerations for and

139. See VA. Code ANN. § 34-17 (1953).

140. See In re Hammonds, 198 Fed. 574 (E.D. Ky. 1912); 3 ReMrngton $\$ 1278$.

141. See Schwartz v. Seldon, 153 F.2d 334 (2d Cir. 1945); In re Dudley, 72 F. Supp. 943 (S.D. Cal. 1947), aff'd, 166 F.2d 1023 (9th Cir. 1948); O'Donnell v. Segar, 25 Mich. 367 (1872); Comstock v. Bechtel, 63 Wis. 656, 24 N.W. 465 (1885); Oglebay, Some Developments in Bankruptcy Law, 22 Rer. J. 41, 44 (1948).

Moreover, the conversion is not vulnerable as a "preference" or a "fraudulent conveyance." In re Driscoll, 142 F. Supp. 300 (S.D. Cal. 1956) (preference); In rc Hammonds, 198 Fed. 574 (E.D. Ky. 1912) (fraudulent conveyance).

142. See Crawford v. Sternberg, 220 Fed. 73 (8th Cir. 1915).

143. See Forsberg v. Security State Bank, 15 F.2d 499 (8th Cir. 1926); Meigs v. Dibble, 73 Mich. 101, 40 N.W. 935 (1888).

144. See In re Wilson, 123 Fed. 20 (9th Cir. 1903); In re Hammonds, 198 Fed. 574 (E.D. Ky. 1912).

145. See Riddell v. Shirley, 5 Cal. 488 (1855) ; Hollins, Burton \& Co. v. Webb, 2 Shann. Cas. 581 (Tenn. 1877); 3 ReMrngton $\$ 1278$; cf. N.Y. INs. Law $\$ 166$ (proceeds of insurance exempt except where intent to defraud creditors exists).

146. Shanks v. Hardin, 101 F.2d 177 (6th Cir. 1939).

147. Compare O'Donnell v. Segar, 25 Mich. 367 (1871) (conversion of nonexempt property into exempt oxen for purpose of acquiring exemption not such fraud as will bar 
against exemption of newly acquired assets are often evenly balanced. Difficulties could be largely avoided, however, if the act treated the acquisition of exempt property on the eve of bankruptcy in essentially the same way it treats "preferential" transfers or voidable judicial liens. ${ }^{148}$ Thus any claim to an exemption in property acquired while the debtor is insolvent and within four months prior to bankruptcy would be disallowed. This would presumably allow the debtor those exempt assets which he owned when credit was still being extended, but prevent him from defeating valid creditors' claims by investing their funds in exempt assets. To prevent hardship, appropriate exceptions to the general rule would allow the debtor to retain exempt assets purchased to replace others, to provide the means of entrance into a new livelihood, or to achieve any other purpose which the bankruptcy tribunal, as a court of equity, finds justifiable.

\section{The Effect of the Debtor's Domicile}

Situations can arise in which the use by section 6 of "domicile" as a determinant of the availability of state debtor relief will deprive individuals of all exemptions. ${ }^{149}$ The section allows exemptions of the state "wherein they [bankrupts] have had their domicile for the six months immediately preceding the filing of the petition, or for a longer portion of such six months than in any other State ...." Bankruptcy counts, however, may administer the estates of insolvents who have either "had their principal place of business, resided or had their domicile within their respective territorial jurisdiction ... or who ... have property within their jurisdictions." 150 Accordingly, a person who relinquishes state domicile to move to a foreign country is subject to a bankruptcy proceeding if he has property or a place of business within a bankruptcy court's jurisdiction. But such a bankrupt would be denied any exemption. ${ }^{161}$ If the debtor has dependents who reside in the state where proceedings are brought, the local policy of protecting a debtor's family from

exemption); and Comstock v. Bechtel, 63 Wis. 656, 24 N.W. 465 (1885) (conversion while insolvent and with intent to defraud upheld), with Long v. Murphy, $27 \mathrm{Kan} .375$ (1882) (insolvent debtor not allowed to exchange nonexempt goods purchased on credit into exempt homestead) ; and Hollins, Burton \& Co. v. Webb, 2 Shann. Cas. 581 (Tenn. 1877) (discharge of purchase money lien in order to claim exemption fraudulent to creditors).

148. Bankruptcy Act $\S \S 60,67$ (a).

149. "Domicile" as used in $\S 6$ means more than residence. See In re Liberman, 44 F.2d 661 (S.D. Ala. 1.930); In re Grimes, 94 Fed. 800 (W.D.N.C. 1899).

Under $\S 6$ of the original Act of 1898 a bankrupt would not be entitled to any state exemptions if he had not had a domicile in one state for at least three months and a day. 30 Stat. 548. See 1 Collier If 6.04, at 802 n.8.

150. Bankruptcy Act $\$ 2$ (a) (1).

151. See 1 Collier If 6.04, at 801 n.7; of. In re Liberman, 44 F.2d 661 (S.D. Ala. 1930); In re Neidecker, 82 F.2d 263 (4th Cir. 1936) (dictum). See also Nadelmann, Forcign and Domestic Creditors in Bankruptcy Proceedings. Remnants of Discrimination?, 91 U. PA. L. Rev. 601 (1943). 
destitution is undercut. In addition, under state law exemptions are generally available only to "residents." 152 Thus if a migrant was deemed to have no residence in his "home" state (although it could be properly said to be his domicile), he could be denied all exemptions in bankruptcy. ${ }^{153}$

\section{Avoiding Liens Upon and Transfers of Exempt Property}

The Bankruptcy Act provides in several sections for the recovery of property which the debtor transferred or surrendered to a particular creditor, or to a third party, in order to defeat the claims of all his creditors. Without explanation or apparent justification, these provisions treat the recovery of exempt property inconsistently. Exempt property is specifically excluded from the reach of section 67 (d), the act's "fraudulent conveyance" provision, ${ }^{154}$ which enables the trustee to avoid a transfer if, inter alia, it is made for less than adequate consideration or with actual intent to defraud creditors. ${ }^{155}$ Similarly, the courts have uniformly held that a transfer of exempt property to a favored creditor on account of an antecedent debt is not "preferential" and thus can not be retrieved by the trustee under section $60 .{ }^{156}$ In contrast, the trustee utilizing

152. See, e.g., Minn. Stat. Ann. $\$ 550.37(18)$ (1947); Mont. Rev. Code Ann. § 93-5813 (1947); Neb. Rev. Stat. AnN. § 25-1556 (1948).

If the bankrupt is not a resident at the precise date his exemption is determined his claim will be denied, even if he was a resident before and since that date. In re O'Hara, 162 Fed. 325 (M.D. Pa. 1908).

153. Although research reveals no cases where a bankrupt has a domicile but not a residence, the possibility has been recognized. See Seccomb v. Bovey, 135 Minn. 353, 355, 160 N.W. 1018, 1019 (1917). Traveling salesmen or seamen might fit into this category. But see 1 BEALE, CoNflict of LAws $\S 10.12$ (1935) (citing two cases for the proposition that residence in exemption statutes may mean "domicile").

154. Bankruptcy Act $\$ 67$ (d) (1), modeled on the UNIFORM Fraudulent ConveYANCE ACT, provides that “'property' of a debtor shall include only his nonexempt property." Compare the use of the term property in the definition of insolvency in $\S 1(19)$, which includes both exempt and nonexempt assets.

The Uniform Fraudulent Conveyance Act varies slightly. Section 1 provides that "'assets' of a debtor means property not exempt from liability for his debts. To the extent that any property is liable for any debts of the debtor, such property shall be included in his assets." Although no case appears to have so held, the latter sentence would seem to enable a creditor to whom property is not exempt to invoke the act. Cf. Peoples State Bank v. Karlen, 44 S.E. 82, 182 N.W. 531 (1921) (implying that the transfer of a homestead which exceeded in value the statutory maximum could be fraudulent to creditors). The Uniform Act has been adopted by twenty states, 9B U.L.A. 10 (Supp. 1958).

155. See First Nat'l Bank v. Wilson, 283 Minn. 160, 47 N.W.2d 764 (1951) (conveyance of homestead under the Uniform Act cannot be set aside as fraudulent, even though debtor conveying property intends to defraud his creditors).

The general rule that a conveyance of exempt property which if nonexempt would be fraudulent can not be set aside rests on the theory that since title to exempt property can not vest in the trustee and the property is not an asset of the bankrupt estate, general creditors have no concern over its disposition. Sieg v. Greene, 225 Fed. 955 (8th Cir. 1915).

156. In contrast to Bankruptcy Act $\S 67(d)$, which specifically excludes exempt property from its scope, see note 154 supra, $\S 60$ (a) defines a preference as the transfer 
section $70(\mathrm{e})$, which permits him to set aside transfers voidable by any creditor under state law, may therefore defeat both fraudulent and preferential transfers of exempt property, since some states treat these conveyances no differently than conveyances of nonexempt property, reasoning that the debtor has waived the property's immunity by his conduct. ${ }^{157}$ Finally, section 67 (a), which dissolves judicial liens obtained on the property of an insolvent within four months of bankruptcy, can furnish the means for reacquisition by the debtor (or perhaps the trustee) ${ }^{158}$ of generally exempt assets. ${ }^{159}$

\section{Section 67(a)}

The obvious purpose of section $67(a)$ is to foster equality of distribution among general creditors by setting aside liens on nonexempt property obtained in a creditors' race. Therefore the section sets aside for the benefit of the estate any lien which meets its requirements. ${ }^{160}$ But shortly after the act was passed, the Supreme Court held, in Chicago, B. \& Q.R.R. v. Hall, ${ }^{161}$ that it might also be used for the debtor's benefit to avoid a lien upon exempt property, although a race to attach exempt property is generally impossible. Hall, an employee of the defendant railroad, was domiciled and employed in Nebraska, where wages were exempt. While temporarily in Iowa, where wages were subject to creditors' claims and Nebraska's exemptions not recognized, two Nebraska creditors served Hall and garnished the railroad. ${ }^{\mathbf{1 6 2}}$ While the Iowa action was pending, Hall was adjudicated a bankrupt in Nebraska and sued the railroad there to recover his back pay. ${ }^{163}$ Finding a

of "any of the property of a debtor . . . while insolvent and within four months" of bankruptcy to satisfy an antecedent debt. See note 179 infra. Nonetheless, the courts have refused to avoid the preferential transfer of exempt property on the same theory that they apply to fraudulent conveyances. See note 155 supra and cases cited in note 182 infra. See also Huntington v. Baskerville, 192 Fed. 813 (8th Cir. 1911); Vitzthum v. Large, 162 Fed. 685 (N.D. Iowa 1908) (dictum).

157. See 1 Collier If 6.11; Annot., 161 A.L.R. 1009, 1020 (1946) (collecting cases).

158. See text at notes 172-73, 190-94 infra.

159. See Chicago, B. \& Q.R.R. v. Hall, 229 U.S. 51.1 (1913), 1 VA. I. Rev. 64 (1913), 14 Colum. L. Rev. 64 (1914). See also Note, 40 VA. L. Rev. 83 (1954).

Bankruptcy Act $\$ 67$ (a) (1) provides:

Every lien against the property of a person obtained by attachment, judgment, levy, or other legal or equitable process or proceedings within four months before the filing of a petition initiating a proceeding under this Act by or against such person shall be deemed null and void (a) if at the time when such lien was obtained such person was insolvent....

160. 4 CoLLIER $\{67.01$.

161. 229 U.S. 511,515 (1913).

162. Id. at 511-13.

163. See the opinion below, Hall v. Chicago, B. \& Q.R.R., 88 Neb. 20, 128 N.W. 645 (1910) (refusing to recognize the Iowa judgments against Hali). The Nebraska court did not think that such a holding imposed a double liability on the railroad since the Iowa judgments were a nullity. But if the railroad had notified the debtor of the pending garnishment proceeding, and upon his default, raised as a defense to garnishment his 
"general policy" in the act to enable the debtor to secure a discharge and "start afresh with the property set apart to him as exempt,"164 the Supreme Court held that the Iowa judgment was not entitled to full faith and credit since section 67 (a) (1) nullified the garnishment lien. ${ }^{165}$

In the 1938 revisions of the Bankruptcy Act, Congress codified Hall by providing in section 67 (a) (3) that any property discharged from a lien shall pass "to the trustee or debtor as the case may be."166 Presumably, Congress intended exempt property to pass to the bankrupt and nonexempt to the trustee. ${ }^{167}$ So applied, 67 (a) gives the debtor a windfall. Under the law of some states, favored creditors, such as purchase-money lenders, tort claimants and materialmen may obtain a judicial lien upon exempt property. ${ }^{108}$ The avoidance of these liens for the benefit of the debtor allows him to obtain a larger exemption than is authorized by the state. ${ }^{169}$ Although the Hall case,

exemption rights, it is doubtful that Hall could recover from the railroad any money already paid to the creditors. See Harris v. Balk, 198 U.S. 215 (1905); In re Beals, 116 Fed. 530 (D. Ind. 1902).

164. 229 U.S. at 515.

165. Actually, the court relied on the predecessor of $\S 67$ (a)(1). See 4 ColrIER II 67.03 , at $48 \mathrm{n} .2$.

166. Bankruptcy Act $\$ 67$ (a) (3) provides:

The property affected by any lien deemed null and void under the provisions of paragraphs (1) and (2) of this subdivision a shall be discharged from such lien, and such property ... shall pass to the trustee or debtor, as the case may be, except that the court may on due notice order any such lien to be preserved for the benefit of the estate....

For the legislative history see note 172 infra; Hanna \& MacLachlan, The BankRUPTCY ACT 96 (5th ed. 1953).

Bankruptcy Act $\S 67(a)$ (4) also codified Hall by providing: "The court shall have summary jurisdiction of any proceeding by the trustee or debtor, as the case may be, to hear and determine the rights of any parties under this subdivision a." Prior to $\$ 67$ (a) (4), the trustee, absent consent of a lienholder or possession of the res, could only bring a plenary suit under 67 (a) in a court where the bankrupt might have prosecuted the action if bankruptcy had not intervened. Bankruptcy Act $\$ 23(\mathrm{~b})$; see 4 CoLIIER 1f 67.18. The Supreme Court also permitted the debtor to assert the invalidity of a lien on exempt property in such a proceeding. See Fischer v. Pauline Oil \& Gas Co., 309 U..S. 294, 301 (1940). A previous case had denied this right, thus leaving the debtor without a remedy if the trustee refused to claim on his behalf. Connell v. Walker, 291 U.S. 1 (1934); see In re Burden, 83 F. Supp. 416 (D. Neb. 1949) (discussing the history of $\S 67$ (a) (4)); Oglebay, Some Developments In Bankruptcy Law, 24 REF. J. 24, 25 (1950).

167. See 4 Collier $\llbracket 67.18$.

168. See text at notes 77-83 supra. To the extent creditors claims are not dischargeable the debtor would not receive a windfall by the avoidance of a lien.

169. See Gray v. Arnot, 31 N.D. 461, 154 N.W. 268 (1915) (lien of purchase-money lender avoided); McMains v. Cunningham, 214 Iowa 300, 242 N.W. 106 (1930) (lien of tort claimant) ; Cavanaugh v. Fenley, 94 Minn. 505, 103 N.W. 711 (1905) (garnishment lien).

Mechanics' and materialmen's liens are ordinarily statutory, not judicial, 4 COLIIER I 67.22. They are therefore insulated from avoidance under $\$ 67$ (a) (1). Bankruptcy Act $\$ \$ 67$ (b), (c) ; see Wallace T. Bruce, Inc. v. Najarian, 249 Minn. 99, 81 N.W.2d 282 
on its own facts, achieved the salutary result of preventing an exemption from being defeated because suit was brought in another forum, which failed to apply the exemption statutes of the debtor's domicile, ${ }^{170}$ its extension to avoid judicial liens on exempt property generally subverts the basic bankruptcy scheme of incorporating whatever allowance state law provides. ${ }^{\mathbf{1 7 1}}$

Liens upon exempt property are not invariably set aside to the bankrupt, however, for an exception to section 67 (a) (3)'s provision that property which has been released from a lien "shall pass to the trustee or the debtor, as the case may be" states that the court may upon due notice order the lien "to be preserved for the benefit of the estate."172 Implementation of this language would seem to nullify the Hall doctrine. When a lien is preserved for the estate, the general creditors obtain property which they would otherwise never reach. This advantage is obtained at the expense of either the lienor or the debtor, who has an expectation engendered by the Hall doctrine. Although the exception clause has rarely been invoked, ${ }^{173}$ it, like $H$ all itself, is contrary to the act's basic policy of incorporating state exemptions.

(1957) (mechanics' lien upon homestead not a judicial lien even though it does not arise until an in personam judgment is obtained and docketed). The availability of a statutory procedure, however, does not generally preclude a mechanic's or materialman's lien from arising judicially. See Moffitt v. Denniston \& Partridge Co., 229 Iowa 570, 294 N.W. 731 (1940) (recognizing a judicial lien for work done and materials furnished on a homestead since statute of limitations had run on statutory lien).

If within four months of bankruptcy a lien is acquired on nonexempt property and the asset attains exempt status when bankruptcy ensues, the debtor may set it aside under $\$ \S 67$ (a) (1), (3). In re Burden, 83 F. Supp. 416 (D. Neb. 1949) (attached truck subsequently used as tool of a new trade); Gregory Co. v. Cale, 115 Minn. 508, 133 N.W. 75 (1911) (lien acquired after bankruptcy on exempt property for a debt contracted prior to an enactment exempting it).

Arguably, the act's use of $\S 67$ (a) (1) to avoid liens for the debtor's benefit, while failing to similarly recover fraudulent and preferential transfers of exempt property, can be supported in terms of a distinction between involuntarily suffering a lien and voluntarily transferring property. But the distinction vanishes when a debtor who could discharge the underlying debt by payment allows a lien to attach.

170. See text accompanying notes 160-65 supra.

171. See 3 Remington $\S 1290$.

Occasionally the Hall doctrine has been ignored. See, e.g., In re Snyder, 216 Fed. 989 (M.D. Pa. 1914); Blake v. Alswager, 55 N.D. 776, 215 N.W. 549 (1927). Moreover, it does not avoid liens acquired by contract or waiver since $\$ 67$ (a) (1) applies only to judicial liens. See In re Goldberg, 254 Fed. 440 (E.D. Pa. 1918); Equitable Credit Co. v. Miller, 164 Ga. 49 , 137 S.E. 771 (1927).

172. Bankruptcy Act $\S 67$ (a) (3). This language's purpose was the prevention of the avoidance of a lien under $\S 67$ (a) (1) accruing to the benefit of a junior creditor. 4 CoLLIER โ 67.16 .

173. Although the clause may be more frequently utilized than the reports indicate, there are only a few reported cases. See Hemsell v. Rabb, 29 F.2d 914 (5th Cir. 1929) (preserving a creditor's lien obtained prior to debtor's acquisition of the encumbered homestead for the estate, since under state law debtor was only entitled to the equity above such a lien); In re Porter, 3 F. Supp. 582 (S.D. Fla. 1933) (same). In these 
Finally, section 67 (a)'s application is inconsistent with Lockwood $v$. Exchange Bank. ${ }^{174}$ Under Lockwood the bankruptcy court will withhold discharge in order to give a creditor sufficient time to perfect a lien on exempt property in a state court. Since 67 (a) will only avoid a prebankruptcy lien, a wise creditor who is able to reach exempt property will delay attachment until after bankruptcy proceedings have begun, and thereby take advantage of Lockwood. Furthermore, if a court attempted to follow both Lockwood and Hall, the result would be a senseless merry-go-round. The court would be obliged first to avoid a prebankruptcy lien for the benefit of the debtor, and then delay discharge to allow the creditor to reobtain his lien. ${ }^{175}$

\section{Section $67(d)$}

In contrast to $67(\mathrm{a})$ 's inconsistent application, section 67 (d) has never been used to recover, for either the bankrupt or the estate, exempt property conveyed in situations which would render a similar transfer of nonexempt assets "fraudulent" under the act.176 The goal of protecting the bankrupt or his general creditors would not require the opposite result. When a debtor voluntarily transfers exempt property for inadequate consideration, he presumably feels that the transfer is to his benefit. ${ }^{177}$ And so long as the asset is, in fact, exempt from their claims, general creditors are no more prejudiced than if he had retained it. ${ }^{\mathbf{1 7 8}}$

instances, however, $\S 67$ (a) (3) was not used for its supposed purpose-prevention of a lien being avoided for the benefit of a junior creditor. See note 172 stipra.

For other instances when a lien on exempt property is preserved for the benefit of the estate, see 1 ColIIER $\{6.12$, at 847 n.6.

174. 190 U.S. 294 (1903), discussed in text at notes 116-21 supra.

175. Cf. Northern Shoe Co. v. Cecka, 22 N.D. 631, 135 N.W. 177 (1912) (creditor not estopped from obtaining a new lien on exempt property after bankruptcy proceedings had commenced, even though he had abandoned enforcement of a prebankruptcy lien which could have been avoided under $\$ 67(a)(1))$.

176. See notes 154-55 sipra and accompanying text, stating the general rule. When, however, property transferred or encumbered exceeds in value the amount of the exemption allowed, the transfer or encumbrance is voidable to the amount of such excess. First Nat'1 Bank v. Lanz, 202 Fed, 117 (5th Cir. 1913). Further, when in a conveyance both exempt and nonexempt property are commingled, it is voidable as to the nonexempt property. Gylling v. Kjergaard, 293 Fed. 676 (Sth Cir. 1923).

177. Arguably, when a debtor has made a fraudulent transfer of exempt property, he has surrendered any protection to which his family would be entitled. However, this argument goes too far. Since the property is exempt, the debtor should be able to utilize it in ways which benefit him. For example, he might have conveyed a valuable homestead for $\$ 1$ to his son to make the son independent. Such a conveyance has a legitimate family motive which ought to be recognized by the courts. Likewise, a debtor may execute a conveyance of exempt property, otherwise fraudulent, to establish good relations with a creditor. If the debtor expects to receive a benefit for himself and his family, the law should not frown on such a transfer.

178. See Sieg v. Greene, 225 Fed. 955, 958 (8th Cir.), rehearing denied, 227 Fed. 41 


\section{Section 60}

Presently, bankruptcy courts also leave preferential transfers of exempt property undisrupted. But arguments can be advanced that section 60 is the most proper path to the bankrupt's recovery of such property. ${ }^{179}$ Situations can be easily imagined in which an honest debtor transfers exempt assets to a particularly insistent creditor in order to satisfy an antecedent debt. This may well have been done in order to deter the creditor from initiating bankruptcy proceedings, with the hope that once the obligation was satisfied economic stability would be revived. 180 When the debtor's expectation is defeated in the event, he finds himself in liquidation without the cushion of his exemptions. To be sure, using section 60 to recover property for the bankrupt's benefit may be a quasi-charitable intervention on behalf of an individual who might have protected himself and his family by more prudent behavior. But a creditor's insistence may be effectively irresistible if the alter-

(Sth Cir. 1915) ; Bohannon v. Clark, 25 Ky. I. Rep. 1710, 78 S.W. 479 (Ct. App. 1904); Sneed v. Davis, 135 Fla. 271, 184 So. 865 (1938).

An exception to the harshness of the general rule might be advisable. Where the debtor can demonstrate that a creditor coerced him into making a fraudulent transfer, by threatening bankruptcy, for instance, the transfer of exempt property should be recovered for his benefit. However, a number of obstacies must be overcome if this course is to be followed. Section 67 (d) expressly excludes its application to exempt property. A more flexible approach might allow the trustee to intervene when equity requires. Another difficulty is presented by the rule that exemptions are determined at the time of the petition. White v. Stump, 266 U.S. 310 (1924). Thus, if the debtor has fraudulently deeded exempt property prior to bankruptcy, he would not own it at the date of petition. See In re Wishnefsky, 181 Fed. 896 (D.N.J. 1910). If the fraudulent deed is considered void $a b$ initio, however, this conceptual hurdle could be overcome. See Stewart v. Black, 143 Ore. 291,22 P.2d 336 (1933). Finally, the provisio to $\S 6$ which disallows an exemption out of transfers avoided under the act, see text at note 190 infra, would have to be made discretionary rather than mandatory.

179. To effect a "preferential transfer" within the meaning of $\$ 60(a)$, the debtor must (1) transfer property (2) to or for the benefit of a creditor (3) for or on account of an antecedent debt (4) while insolvent and (5) within four months of bankruptcy. If the requirements of $\$ 60(\mathrm{a})$ are met, the trustee is authorized in $\S 60(\mathrm{~b})$ to avoid the transfer, providing that "the creditor receiving it or to be benefited thereby or his agent ... has, at the time when the transfer is made, reasonable cause to believe that the debtor is insolvent."

Since $\$ 60(a)$, unlike $\S 67(d)$, does not exclude exempt property, it could be applied to such property. However, an amendment to the proviso of $\$ 6$ would be necessary. See note 190 infra. The allowance of an exemption out of recovered preferentially transferred property is also subject to the conceptual objection that exemptions are determined as of the petition date. See note $17 \mathrm{~S}$ supra. See also In re White, 109 Fed. 635 (W.D. Mo. 1901).

1SO. A preference does not require any intent to hinder, delay or defraud creditors. 3 Collies $\int 60.03$; see In re Armory and Leeds, 1 Fed. Cas. 788 (No. 336c) (C.C.S.D. N.Y. 1S44) (preference which was procured by threats to bring action on their claims upset for general creditors); Rison v. Knapp, 20 Fed. Cas. 835 (No. 11861) (E.D. Ark. 1868) (preference upset for general creditors even though made under pressure and with expectation that all debts would eventually be paid). 
native is bankruptcy, and the basic theory behind discharging a debtor with sufficient assets to start afresh is help to those who could not help themselves. ${ }^{181}$ Nor would the debtor's recovery of preferentially conveyed exempt property be unjust to either the general creditors or the transferee. General creditors ordinarily have no interest in such property, ${ }^{182}$ and since the transferee could not retain similarly conveyed nonexempt property, he should not be benefited because the debtor relinquished assets which, according to state policy, are necessary for his support and rehabilitation. The costs of recovery, however, should be borne by the debtor rather than the general creditors. ${ }^{183}$ Thus, the exempt property could be returned to the trustee, who would recover his expenses therefrom before relinquishing it to the bankrupt. ${ }^{184}$

\section{Section 70(e) and the Proviso to Section 6}

Related problems are raised by section $70(\mathrm{e})$ which enables the trustee to assert the rights of a creditor under state law. Generally, 70(e) is unavailing in the recovery of exempt property, since most states hold such a conveyance is neither fraudulent nor preferential. ${ }^{185} \mathrm{~A}$ few states, however, allow creditors to attack transfers of exempt assets reasoning that the transferee is not entitled to the debtor's exemption as a defense. ${ }^{186}$ In those instances where exempt property was recovered, the bankruptcy courts, purporting to follow state law answered the question of its ultimate disposition different-

181. See Chicago, B. \& Q.R.R. v. Hall, 229 U.S. 511 (1913).

182. See Schwartz v. Holzman, 69 F.2d 814 (2d Cir. 1934); Baumbaugh v. Los Angeles Morris Plan Co., 30 F.2d 816 (9th Cir. 1929); First Nat'l Bank v. Lanz, 202 Fed. 117 (5th Cir. 1913).

183. The law would be a mockery, and permit a party to take advantage of his own wrong, if after having transferred his property ... and compelling the trustee in bankruptcy, at the expense of the estate, to engage in protracted litigation ... and recover the proceeds of the property ... the bankrupt could ... come in and [claim his exemption] ....

In re White, 109 Fed. 635, 637 (W.D. Mo. 1901).

Even though the debtor pays the administrative costs, general creditors may be prejudiced. Since the transferee will become a general creditor after the avoidance, the same estate will be divided among a larger amount of claims.

184. Cf. In re Collier, 93 Fed. 191. (W.D. Tenn. 1899) (where no assets are in the estate, administrative costs may be paid out of exempt property); In re Kane, 127 Fed. 552 (7th Cir. 1904) (where bankrupt demands exemption in cash instead of property and property is sold, bankrupt must bear proportionate share of expenses of sale). Contra, Dunlap Hardware Co. v. Huddleston, 167 Fed. 433 (5th Cir. 1909).

185. See Sneed v. Davis, 135 Fla. 271, 184 So. 865 (1938) (no fraudulent conveyance of exempt property) ; Jackson v. Jetter, 160 Iowa 571, 142 N.W. 431 (1913) (same); Kleinert v. Lefkowitz, 271 Mich. 79, 259 N.W. 871 (1935) (same); Bank of Mendon v. Mell, 185 Mo. App. 510, 172 S.W. 484 (1914) (no preference of exempt property); Herring v. Whitford, 119 Neb. 725, 230 N.W. 665 (1930) (same).

186. See Bandy v. Taylor Iron Works \& Supply Co., 177 Ga. 455, 170 S.E. 368 (1933) ; Tilton v. Sanborn, 59 N.H. 290 (1879). 
ly. ${ }^{187}$ Some, mindful of the welfare of the bankrupt and his family and wary of allowing a windfall to the general creditors, allowed title to revest in him, ${ }^{188}$ while others accorded the property to the trustee, conceiving of the transfer as the debtor's abandonment of his interest. 189

To resolve this conflict and to prevent a bankrupt from obtaining an exemption in property recovered by the trustee, ${ }^{190}$ the 1938 revision added a proviso to section 6 which supersedes state law by disallowing any claim to an exemption "out of the property which a bankrupt transferred or concealed and which is recovered or the transfer of which is avoided under this Act for the benefit of the estate ...." Despite its broad language, the scope of the proviso appears to be limited. ${ }^{191}$ Arguably, it could overrule the Hall doctrine (allowing the debtor to recover property freed from a lien by section $67(a)$ ), for the Bankruptcy Act's definition of a "transfer" includes the sufferance of a lien. ${ }^{102}$ Congress apparently did not intend this result, for it contemporaneously codified Hall. Moreover, the proviso does not attempt to alter the prior rule that sections 67 (d) and 60 do not comprehend exempt property, or to expand section 70(e)'s use of state law to similarly set aside fraudulent or preferential transfers. ${ }^{193}$ Therefore, it provides nothing more than a uniform rule of bankruptcy distribution in those few states where creditors may set aside conveyances of exempt property. ${ }^{194}$

187. Compare Arbogast v. Gottfried, 58 F.2d 156 (6th Cir. 1932) (allowing an exemption in a recovered preference because Ohio law allows a debtor to claim an exemption out of a recovered fraudulent conveyance); and In re Arnall, 285 Fed. 654 (N.D. Ga. 1923) (dictum), with Hyman v. Stern, 43 F.2d 666 (4th Cir. 1930) (no exemption allowed out of recovered property fraudulently concealed).

188. See In re Falconer, $110 \mathrm{Fed} .111$ (Sth Cir. 1901) (preference); Cox v. Wilder, 6 Fed. Cas. 684 (No. 3308) (C.C.E.D. Mo. 1872) (fraudulent conveyance); Vaughn v. Vaughn, 262 Ky. 181, 89 S.W.2d 884 (1936) ; Kleinert v. Lefkowitz, 271 Mich. 79, 259 N.W. 871 (1935).

189. In re Wishnefsky, 181 Fed. 896 (D.N.J. 1910); In re White, 109 Fed. 635 (W. D. Mo. 1901). See also In re Denson, 195 Fed. 857 (N.D. Ala. 1912) (exemption not allowed in fraudulently concealed assets).

190. H.R. Rep. No. 1409, 75th Cong., 1st Sess. 9 (1937); see In re Grisanti, 58 F. Supp. 646 (W.D. Ky. 1945) (Bankruptcy Act now provides uniform rule).

191. The language of the proviso would indicate its application to conveyances in "good" as well as "bad faith." Thus, it would deny an exemption even when a general assignment for the benefit of all creditors was set aside under the Act. See 3 Rearington $\$ 1276$. But see 1. Collier $\int 6.11$ (criticizing this possible result).

192. Bankruptcy Act $\S 1(30)$. As far as can be determined, this argument has never been raised as a defense to the avoidance of a judicial lien on exempt property under $\$ 67$ (a). See 3 ReArington $\$ 1277$.

193. See 1 Collier |f 6.11. See also Annot., 161 A.L.R. 1009, 1013 n.1.1 (1946).

194. Some courts have avoided reaching any problem under the proviso by holding that a transfer of exempt property results in a waiver by the debtor of any exemption rights in the property. See Gardner v. Johnson, 195 F.2d 717 (9th Cir. 1952), 26 So. CAI. L. REv. 87. But see Negin v. Salomon, 151 F.2d 112 (2d Cir. 1945) (transfer of part of exempt property does not result in waiver of exemption in rest). There are, of course, other circumstances under which the trustee may recover exempt property even though 
The effect of the 1938 amendment to section 6 is further diluted by an unexplained exception clause, which provides that "where the voided transfer was made by way of security only and the property recovered is in excess of the amount secured thereby, such allowance [an exemption] may be made out of such excess." Although this language has not yet been construed, ${ }^{105}$ it may seriously undercut the proviso's purpose of recovering for the estate fraudulently or preferentially conveyed exempt property. Assume, for example, that a debtor mortgages a $\$ 5000$ homestead to secure a $\$ 500$ loan. If the transaction constitutes a fraudulent conveyance under state law, the trustee can set is aside via section $70(\mathrm{e})$. But if the mortgagee lacks fraudulent intent he will normally be entitled to repayment out of the property, ${ }^{196}$ and the debtor, according to the exception clause, will receive the $\$ 4500$ balance, thus leaving nothing for the general creditors. A similar result obtains if the mortgage was a preferential transfer, made to secure an antecedent debt, except that the estate will be entitled to receive $\$ 500$ from the recovered property, the bankrupt the excess, and the mortgagee will have to claim as a general creditor. ${ }^{197}$ Since the language of the exemption is permissive the debtor's rights thereunder depend upon judicial discretion, but neither the statute nor its legislative history provides any standards to guide the courts. ${ }^{108}$

The statutory scheme, created by section $70(\mathrm{e})$, the proviso to section 6 , and its exception, neither faithfully incorporates state exemption policy nor

he is unable to set aside a fraudulent or preferential transfer of exempt property under state or federal law. See, e.g., In re Coddington, 126 Fed. 891 (M.D. Pa. 1904) (surrender by the transferee) ; 1 CoLlier $\Uparrow 6.11$; cf. 3 Renrington $\$ 1276.5$ (where the bankrupt conceals nonexempt property which is not recovered and the value of such property is proved, it may be charged against any allowable exemptions).

195. In the only two cases involving a security transfer of exempt property in excess of the secured debt, the courts have ignored the exception clause and disallowed any exemption. In re Grisanti, 58 F. Supp. 646 (W.D. Ky. 1945) (fraudulent transfer) ; In re Ragozzino, 38 F. Supp. 53 (E.D.N.Y. 1941) (bad faith on part of bankrupt in failing to list exempt asset in his initial schedule).

196. Uniform Fraudulent Conveyance Act \$ 9(2) provides: "A purchaser who without actual fraudulent intent has given less than a fair consideration for the conveyance or obligation, may retain the property or obligation as security for repayment."

197. A requirement of a preference under state law is reasonable belief of the transferor's insolvency by the transferee. If the transfer qualifies as a preference, the transferee retains nothing. See 2 Glenn, Fraudulent Conveyances and Preferences $\$ 390$ (rev. ed. 1940).

198. The purpose of the exception to the proviso is ambiguous. One of the authorities, who testified at the hearings, states: "The exception ... . was intended to give a bankrupt the benefit of any excess recovered over the amount of the debt secured; to the extent of such excess, the estate is not deprived of the property and thus has not been harmed." Weinstein, The BankRuptcy LAW of 1938, at 30 (1938). This explanation apparently ignores the fact that the estate ordinarily recovers the amount of the debt, in which the general creditors have no greater interest than in the excess and as to which they have equally "not been harmed."

Hanna \& McLachlan, The Bankruptcy Act 19 (5th ed. 1953), suggest that the exception should not be applied where the security conveyance was fraudulent. 
provides a truly uniform bankruptcy rule for recovering transfers of exempt property. The former goal is defeated, because the bankrupt's right to exempt property recovered under section $70(\mathrm{e})$ is governed by section 6 , and therefore largely depends upon whether or not the avoided transaction was a security agreement, while the states usually deny this right. ${ }^{109}$ Conversely, uniformity is not achieved, because section 6's proviso is with few exceptions ${ }^{200}$ operative only in those instances when state law, as incorporated by section 70 (e), is controlling. A uniform bankruptcy rule, with no ties to state law, appears desirable. Perhaps the most satisfactory solution is the previouslysuggested amendments of sections 60 and $67(\mathrm{~d}),{ }^{201}$ followed by the restriction of $70(\mathrm{e})$ 's operation in exempt-property cases ${ }^{202}$ and the repeal of the proviso to 6 . Thus, transfers of exempt property shortly before bankruptcy would be normally undisturbed, although the asset would be returned to the debtor under section 60 according to the merits of the particular case and under 67 (d) when the "fraudulent" conveyance is the result of coercion. In this manner, the interests of the debtor and both general and special creditors will be equitably balanced throughout the act.

\section{The Ideal Lien Creditor and Exempt Property}

Section 70 (c), vesting in the trustee all property of the debtor upon which a creditor (real or imaginary) could have obtained a lien at the date of bankruptcy, ${ }^{203}$ enables general creditors to strip the bankrupt of virtually any exemption he may be entitled to under the state law. The potency of this provision was dramatically demonstrated in the Ninth Circuit case of Samsell v. Straub. ${ }^{204}$ There, section 70 (c) defeated a California homestead exemption which no existing creditor could have successfully challenged. In California,

199. Even in the few states which allow a tainted conveyance of exempt property to be set aside, the action is almost invariably for the benefit of creditors and not the debtor. See Bandy v. Taylor Iron Works \& Supply Co., 177 Ga. 455, 170 S.E. 368 (1933) ; Tilton v. Sanborn, 59 N.H. 290 (1879). But cf. Roig v. Schults, 42 Ohio St. 165 (1884) (exemption allowed a debtor after creditor set aside the transfer).

200. See note 194 supra.

201. See notes 176-\$4 supra and accompanying text.

202. Denying application of $\S 70(\mathrm{e})$ to exempt property will give the trustee less power than creditors have in those states allowing an attack on tainted transfers of exempt property. See text at note 186 supra. Such a result is justified in view the desirability of leaving uncoerced transfers alone. See text at notes 176-84 supra.

203. Bankruptcy Act $\S 70$ (c) provides:

... The trustee, as to all property, whether or not coming into possession or control of the court, upon which a creditor of the bankrupt could have obtained a lien by legal or equitable proceedings at the date of bankruptcy, shall be deemed vested as of such date with all the rights, remedies, and powers of a creditor then holding a lien thereon by such proceedings, whether or not such a creditor actually exists.

204. 194 F.2d 228 (9th Cir. 1951), cert. denied, 343 U.S. 927 (1952), 31 Texas L. REv. 64 (1952). 
as in many other states, a householder has no homestead exemption rights without filing. ${ }^{205}$ Although under California law he can generally record his homestead any time before judicial sale, ${ }^{206}$ a judgment creditor whose lien is docketed prior to recordation will prevail. ${ }^{207}$ The bankrupt in Samsell had not recorded prior to the petition, and therefore the trustee, wearing the hat of a non-existent judgment creditor who had docketed his lien, successfully defeated the exemption. ${ }^{208}$ Although no cases appear to have carried section 70 (c) to its logical extreme, ${ }^{209}$ there is no reason why the trustee could not defeat virtually every exemption by playing the role of a creditor as to whom the property is non-exempt. Many states, for example, provide that exempt property is available to a purchase-money lender. ${ }^{210}$ Presumably the trustee could thus obtain title to the asset. Similarly, wage exemptions could be de-

205. Cal. Civ. Code Ann. § 1262 (1954); see Comment, 26 Calif. L. Rev. 241 (1938).

State requirements for recordation of homesteads vary. In most states filing of homestead declarations is not necessary. Annot., 145 A.L.R. 501, 502 (1943). In states requiring the filing of a homestead declaration, one type of statute requires declaration to be made prior to levy. See In re Youngstrom, 153 Fed. 98 (8th Cir. 1907) (Colo.). In these states the debtor must have filed his declaration prior to the petition in bankruptcy in order to obtain the exemption. White v. Stump, 266 U.S. 310 (1924), 25 Colur. L. REv. 492 (1925). A second type of statute allows a debtor to keep his homestead by filing a declaration anytime prior to the execution sale. See Georgouses v. Gillen, 24 F.2d 292 (9th Cir. 1928). In these states, a declaration after adjudication in bankruptcy will suffice. Myers v. Matley, 318 U.S. 622 (1943), 43 CoLuMr. L. REv. 227. Finally, several states allow a homestead to be claimed even after execution sale. See North Dakota v. Schafer, 131 F.2d 9 (8th Cir. 1942); In re Carl, 38 F. Supp. 414 (W.D. Ark. 1941).

206. In re Curmar Mfg. Co., 91 F. Supp. 647, 648 (S.D. Cal. 1950) (under California law a lien of execution is not sufficient to defeat a declaration made after levy of execution and before sale), aff'd on other grounds sub nom. Sampsell v. Straub, 189 F.2d 379, rev'd on other grounds on rehearing, 194 F.2d 228 (9th Cir. 1951), cert. denied, 343 U.S. 927 (1952).

207. Sampsell v. Straub, 194 F.2d 228 (9th Cir. 1951) ; Schuler-Knox Co. v. Smith, 62 Cal. App. 2d 86, 144 P.2d 47 (Dist. Ct. App. 1943).

208. This result was reached on rehearing. Sampsell v. Straub, 194 F.2d 228 (9th Cir. 1951), cert. denied, 343 U.S. 927 (1952). In its original decision, the Ninth Circuit refused to apply $\S 70(\mathrm{c})$ on the grounds that under local law the only lien which would defeat the declaration was one obtained by docketing an in personam judgment, and that such a lien was not obtained by "legal or equitable proceedings." Sampsell v. Straub, 189 F.2d 379 (9th Cir. 1951); see 50 MICH. L. REv. 925 (1952) (criticizing the result); 27 N.Y.U.L. Rev. 146 (1952) ; 100 U. PA. L. REv. 453 (1951).

209. Only recently have courts begun employing $\$ 70(\mathrm{c})$ to defeat exemptions. See England v. Sanderson, 236 F.2d 641 (9th Cir. 1956) (discussed in note 216 infra).

Section 70 (c) has also been employed to achieve results similar to those under $\S 67$ (a). The Seventh Circuit hypothesized an "ideal" creditor to defeat an unrecorded mortgage on exempt property valid between the bankrupt-mortgagor and mortgagee and returned the property to the debtor. In re Urban, 136 F.2d 296 (7th Cir. 1943). Subsequent$1 y$, however, the state court mitigated this result by awarding the exempt property to the mortgagee. Charnesky v. Urban, 245 Wis. 268, 14 N.W.2d 161 (1944).

210. See notes 79-83 supra. 
feated were the trustee to pose as a creditor who obtained a garnishment lien in a foreign state. ${ }^{211}$

Section $70(c)$ is made even more lethal by the Constance v. Harvey ${ }^{212}$ rule that a trustee can not only postulate an ideal lien creditor but can pick the time at which he hypothetically extended credit to the debtor. ${ }^{213}$ This additional assumption enables the trustee to defeat a secured lender when state law allows an unsecured creditor who extended credit during the hiatus between a secured loan and its recordation to subsequently perfect a lien on the property. ${ }^{214}$ Conceivably, this doctrine can permit the trustee to defeat most state exemption increases. Since the contracts clause of the Constitution renders an increase in state exemptions ineffective against a pre-amendent creditor, ${ }^{215}$ Constance might allow the trustee to posit the extension of credit by a hypothetical ideal lienor before the most recent revision, or perhaps before any within the lifetime of the debtor. Thus property presently immune from all actual creditors could be rendered available to the trustee. ${ }^{216}$

The employment of section 70 (c) (with or without the Constance gloss) to defeat an exemption is neither desirable nor necessary. It deprives the

211. See text at notes $94-96$ supra.

212. 215 F.2d 571 (2d Cir. 1954), cert. denied, 348 U.S. 913 (1955).

213. See 4 Collter $\{70.51$, at 97 n.7, 98 (Supp. 1958).

214. In Constance the bankrupt had given a chattel mortgage which remained ineffectively recorded for ten months. Even assuming the mortgage was recorded prior to bankruptcy, the trustee prevailed under $\$ 70$ (c) since according to New York law a late recorded chattel mortgage is void as to simple contract creditors without notice whose claims arise prior to actual recording. Since such a creditor could obtain a lien at the time of the petition, so can the trustee under $\S 70$ (c). Constance v. Harvey, 215 F.2d 571 (2d Cir. 1954), cert. denied, 348 U.S. 913 (1955). See generally 4 ColLIER $\{$ 70.51; Marsh, Constance v. Harvey-The "Strong-Arm Clause" Re-Evaluated, 43 CALIF. L. REv. 65 (1955) (criticizing Constance).

215. See notes $84-89$ supra and accompanying text. The incorporation of state exemptions has been held to extend the inflexibility of state legislation to federal bankruptcy law. See England v. Sanderson, 236 F.2d 641 (9th Cir. 1956); Samuels v. Quartin, 108 F.2d 789 (2d Cir. 1940); In re Towers, 146 F. Supp. 882 (N.D. Cal. 1956), aff'd sub nom. Towers v. Curry, 247 F.2d 738 (9th Cir. 1957). This result would be both unnecessary and illogical. Not only are congressional enactments immune from the constitutional prohibition, but every discharge in bankruptcy impairs the contracts of creditors. Moreover, Bankruptcy Act $\S 6$, which incorporates state exemption laws "in force at the time of filing of the petition," can be read to require that increased state exemptions be applied to contracts antedating the amendment, notwithstanding the constitutional limitations. See In re Richards, 64 F. Supp. 923, 924 (S.D. Tex. 1946); In re Crayton, 56 F.2d 282 (W.D. N.Y. 1932).

216. In England v. Sanderson, 236 F.2d 641 (9th Cir. 1956), the trustee recovered $\$ 5,000$ for the estate-the difference between the $\$ 7,500$ homestead California provided prior to 1945 and the $\$ 12,500$ provided in 1953 . In this case, however, there were in fact creditors whose claims arose prior to the latest California amendment and it was therefore unnecessary for the trustee to hypothesize them. See In re Towers, $146 \mathrm{~F}$. Supp. 882 (N.D. Cal. 1956), aff'd sub nom. Towers v. Curry, 247 F.2d 738 (9th Cir. 1957) (same). 
bankrupt of property which state policy finds necessary for the support of him and his dependents, irrespective of the ability of an actual creditor to invalidate the exemption. Clearly, the section was never intended to work such havoc. Rather it was designed to permit the trustee to recover for the benefit of the estate property on which the debtor had granted a secret lien, ${ }^{217}$ since the trustee formerly acquired only the rights of the debtor, and secret consensual liens are valid between the parties. ${ }^{218}$ Consequently, the section should be amended, or interpreted, to preclude the application of the ideal lien creditor test to exempt property. ${ }^{219}$ This course would not be unjust to an actual creditor who may obtain a lien upon otherwise exempt property since under the Lockwood case he could still perfect his interest in state court.

\section{Waiver of Exemptions}

Although exemptions are in large measure designed to protect the debtor from his own improvidence, both the Bankruptcy Act and some states allow him to waive their benefits. Under state law a failure to file a timely declaration of intent to claim an exemption constitutes an effective waiver. ${ }^{220}$ In addition, some states sanction a contractual waiver of exemption rights in favor of a particular creditor, ${ }^{221}$ and two states hold the right to claim an exemption assignable to the creditor. ${ }^{222}$ Since waivers undermine exemption objectives, other states refuse to enforce them while executory, on grounds

217. See 45 Cong. REC. 2277 (1910).

218. Ibid.; York Mfg. Co. v. Cassell, 201 U.S. 344 (1906); see 4 ColLIER IIT 70.45-.47.

219. This was once the prevailing position of the courts. See Brand v. Mayhew, 218 Fed. 422 (9th Cir. 1914) (such application would defeat the policy of incorporating state exemption); In re Carl, 38 F. Supp. 414 (W.D. Ark. 1941).

220. See, e.g., Acosta v. Whitney Nat'1 Bank, 214 La. 700, 38 So. 2d 391 (1948) (homestead); Gledhill v. Walker, 143 Ohio St. 381, 385-86, 55 N.E.2d 647, 650 (1944) (same); Smith v. Phlegar, 73 Ariz. 11, 19, 236 P.2d 749, 755 (1951) (personalty); Rames v. Norbraten, 65 S.D. 269, 272 N.W. 826 (1937) (same); Tinsley v. Bauer, 125 Cal. App. 2d 724, 732, 271 P.2d 116, 121 (1954) (Dist. Ct. App. same); McKinty v. Butts, 217 I11. App. 234 (1920) (same) ; Gilewicz v. Goldberg, 69 App. Div. 438,74 N.Y. Supp. 984 (1902) (same); Russell v. Dean, 30 Hun. 242 (N.Y. Sup. Ct. 1883) (same).

221. E.g., McCormick Harvesting Mach. Co. v. Vaughn, 130 Ala. 314, 30 So. 363 (1900) ; Lawrence v. Commercial Banking Corp., 165 Md. 559, 169 Atl. 69 (1933); Beatty v. Rankin, $139 \mathrm{~Pa}$ 358, 21 Atl. 74 (1891); Opportunity Bldg. \& Loan Ass'n v. Silverman, 38 Pa. D. \& C. 575 (C.P. 1940); GA. Code Ann. \& 51-1101 (1938). Some jurisdictions which forbid a married debtor to waive, permit one who is single to forego his exemption. E.g., Powell v. Daily, 163 I11. 646, 45 N.E. 414 (1896). The executory waiver is commonly contained in the note evidencing the debt. For some other methods, see 1 COLLIER 介 6.10, at 825 n.3. For an excellent discussion of the early laws and cases, see 2 FreERAN, Executions $\$ 216$ (3d ed. 1900).

222. Lyle v. Roswell Store, Inc., 187 Ga. 386, 200 S.E. 702 (1938); Citizens Bank \& Trust Co. v. Pendergrass Banking Co., 164 Ga. 302, 138 S.E. 223, 226 (1927); Saul v. Bowers, 155 Ga. 450, 117 S.E. 86 (1923) ; In re National Grocer Co., 181 Fed. 33 (6th Cir. 1910) (construing Michigan law); see MrcH. Stat. ANn. $\$ 27.1547$ (1935). 
of public policy, ${ }^{223}$ and those that allow them often restrict their use. For example, waiver of homestead exemptions generally requires signature of the spouse and acknowledgment of the instrument. ${ }^{224}$ Contractual waivers are not enforced in bankruptcy, for under Lockwood the bankruptcy court has no jurisdiction to administer exempt property or to adjudicate conflicting claims therein. But the court will give effect to valid state waivers, by retaining the property and withholding discharge until the waiver creditor has perfected his interest in a state court.

A waiver may also result from a failure to list exempt property in the schedules of assets and liabilities required in bankruptcy. ${ }^{225}$ Since a bankruptcy court will not force the bankrupt to claim an exemption nor allow the waiver creditor to assert it for him, ${ }^{226}$ a bankruptcy waiver makes otherwise exempt property available for distribution to the general creditors. Thus, the waiver is conceptualized as the waiver creditor's security interest, inchoate until an exemption is claimed. ${ }^{227}$

The destruction of a waiver creditor's rights by virtue of a bankrupt's failure to claim an exemption contravenes state policy by giving general creditors property they could not otherwise reach, and denying waiver creditors property they could otherwise obtain. On the other hand, if the bankruptcy courts have ignored waivers of unclaimed exemptions in order to foster a federal policy of debtor protection, ${ }^{228}$ their efforts have been unavailing. So long as a waiver creditor exists and the Lockwood rule withholds discharge to allow him to obtain a state lien, the debtor will lose the property - to the waiver creditor if he claims the exemption, and to the trustee if he

223. E.g., Industrial Loan \& Inv. Co. v. Superior Court, 189 Cal. 546, 209 Pac. 360 (1922); Weaver v. Lynch, 79 Colo. 537, 246 Pac. 789 (1926); Sherwin-Williams Co. v. Morris, 25 Tenn. App. 272, 156 S.W.2d 350 (1941) ; OHio Rev. Code Ann. § 2329.72 (Page 1953); see Annot., 47 A.L.R. 300 (1927).

224. E.g., Ariz. Rev. Stat. ANN. § 33-1104 (1956); Ilr. Rev. Stat. ch. 52, § 4 (1957) ; LA. Const. art. 11, § 3.

225. In re Gerber, 186 Fed. 693, 699-700 (9th Cir. 1911); In re Gunzberger, 268 Fed. 673, 676 (M.D. Pa. 1920); 1 Collier $\llbracket 6.19$, at 872.

226. See Novak v. O'Neal, 201 F.2d 227 (5th Cir. 1953); Leiter v. Steinbach, 184 F.2d 751 (5th Cir. 1950); In re Mattingly, 42 F. Supp. 83 (W.D. Ky. 1941); In re Martin Bros., 294 Fed. 368 (N.D. Ga. 1923). Prior to Novak, at least one court distinguished between a creditor holding a waiver and one holding an assignment, and allowed the latter to prevent the debtor from extinguishing his rights by failing to claim exemptions in bankruptcy. Kronstadt v. Citizens \& So. Nat'l Bank, 80 F.2d 260, 263 (5th Cir. 1935); see 1 CoLurer $\{6.10$, at 826-27. Although purporting to distinguish Kronstadt on its facts, 201 F.2d 227 at 229, Novak seems to have, in effect, overruled it. See 201 F.2d at 232 (dissenting opinion of Hutcheson, C.J., the author of Kronstadt) ; Nadler, Jurisdictional Aspects of Assigned Exemptions, 16 GA. B.J. 178 (1953).

227. See In re Martin Bros., 294 Fed. 368, 370 (N.D. Ga. 1923); 3 REMrtNGTon \$\$ 1313-14, at 238-39; cf. Glenn, Property Exempt from Creditors' Rights of Realization, 26 VA. L. REv. 127, 138 (1939).

228. See In re Martin Bros., supra note 227, at 370; MAdLACHLAN, BANKRUPTCX 164 (1956); Waples, HoMestead and Exemption 540-41 (1893). 
does not. Thus, a debtor's interest in the property is reduced to the power of choosing whether it will go to the trustee or the waiver holder.

While a waiver may serve as a quasi-security device when a borrower has no collateral and a lender nothing else to rely on, ${ }^{229}$ typical waivers apparently include all assets whenever acquired, ${ }^{230}$ and the absence of restrictions on the number of waivers a debtor may execute ${ }^{231}$ and requirements of notice to subsequent lenders give them many of the characteristics of secret, inchoate, floating charges, traditionally condemned in bankruptcy. ${ }^{232}$ Moreover, they are only technically "consensual," since a waiver of exemptions seems to be a standard provision in lender-prepared promissory note forms in those states where waivers are sanctioned. 233

If Congress followed the lead of the majority of the states ${ }^{234}$ by providing that executory consensual waivers will not be recognized when the bankrupt claims his exemption, exemptions would become an even stronger device for debtor rehabilitation. The bankrupt would no longer forego claiming his exemption, since he would receive its benefits. This would not be unduly unjust to the waiver holder, who could still transform his inchoate "security" interest into a judicial lien by reducing his claim to judgment in a state court prior to bankruptcy. Such a lien would not be avoided by section 67 (a) (1), since Hall excluded waiver liens from the operation of that section. ${ }^{235}$

In the unlikely event that a bankrupt fails to claim an exemption, this would operate as a waiver in bankruptcy. But the debtor's abandonment of

229. See Kronstadt v. Citizens \& So. Nat'1 Bank, 80 F.2d 260, 264 (5th Cir. 1935).

230. See Leiter v. Steinbach, 184 F.2d 751, 752 n.1 (5th Cir. 1950) (setting out text of a waiver note).

231. Cf. Novak v. O'Neal, 201 F.2d 227 (5th Cir. 1953) (more than one waiver creditor); Saul v. Bowers, 155 Ga. 450,117 S.E. 86 (1923) (same).

232. "[F]or thirty-five years Congress has consistently reached out to strike down secret transfers, and the courts have with equal consistency found its efforts faulty or insufficient to that end." Corn Exch. Nat'l Bank \& Trust Co. v. Klauder, 318 U.S. 434, 438 (1943). "The committee reported in 1910 that the evil that it had attempted to correct in 1903 and was still struggling with was the prevention of secret liens ...." Hirschfeld v. Nogle, 5 F. Supp. 234, 236 (E.D. I11. 1933).

See Thompson v. Fairbanks, 196 U.S. 516 (1905) (upholding a floating charge on stock in trade in the form of a chattel mortgage). Legislative history indicates that this case typifies some of the evils at which the 1938 bankruptcy amendments were directed. See Hearings on H.R. 6439 Before the House Committee on the Judiciary, 75th Cong., 1st Sess. 121-25 (1937).

See generally H.R. Rep. No. 1409, 75th Cong., 1st Sess. 30 (1937) ; 3 Colirer II 60.37 , at 877, 879, 883, 60.38 at 900; MAcLACHLAN, BankRuptcy 166 (1956).

233. The waiver provisions of the promissory notes set out in the following cases all bear a striking similarity in language. See Leiter v. Steinbach, 184 F.2d 751, 752 n.1 (5th Cir. 1950) ; Kronstadt v. Citizens \& So. Nat'l Bank, 80 F.2d 260, 261 (5th Cir. 1935) ; In re Martin Bros., 294 Fed. 368, 369 (N.D. Ga. 1923) ; Saul v. Bowers, 155 Ga. 450, 117 S.E. 86 (1923); cf. MacLachlan, BankRUPTCY 164 (1956).

234. See cases cited note 223 supra.

235. Chicago, B. \& Q.R.R. v. Hall, 229 U.S. 511, 516 (1913). 
his interest in the asset should not benefit the general creditors at the expense of the waiver holder. The rationale that allowing the court to set aside, for a waiver creditor, unclaimed exempt property would violate Lockwood ${ }^{236}$ is not persuasive. That case held that once property is set off as exempt, the general creditors have no interest therein, and a contest between debtor and waiver creditor must be settled in another forum. But when the bankrupt fails to claim an exemption, a dispute arises between a creditor alleging a superior claim and the other creditors. Such controversies are the traditional meat of bankruptcy. Therefore, if the bankrupt forfeits his exemption, the waiver holder should not be prevented from setting up the generally exempt nature of the property and his special rights.

\section{Exeniptions IN MOdern Society}

State exemptions, sired by the nineteenth-century economy and later adopted by the Bankruptcy Act, have failed to grow up. The dollar has depreciated. Wealth forms and occupational patterns have changed. Economic stability at high living standards has been achieved. New attitudes toward governmental responsibility for financial disaster have developed. ${ }^{237}$ But state exemptions have inadequately responded to these phenomena. Nonetheless, their incorporation in bankruptcy goes virtually unchallenged. ${ }^{238}$ While this Comment has recommended the Act's modification in order to delete inconsistencies or self-defeating provisions, it has thus far assumed continued bankruptcy utilization of state exemptions. More basic reform may, however, be warranted. This section will consider the contemporary need for exemptions, and explore alternative methods of reaching their underlying goal of debtor relief and rehabilitation.

\section{Social Welfare Legislation-A Complete Alternative?}

Although the exclusion of specified assets from creditors' claims may have seemed to be the only proper means of debtor rehabilitation in an era which emphasized individual incentive and responsibility, ${ }^{239}$ the recent development of welfare legislation suggests that the community, rather than creditors,

236. See Novak v. O'Neal, 201 F.2d 227, 231-32 (5th Cir. 1953).

237. See Clarke, Soctal Legrslation 443 (2d ed. 1957) [hereinafter cited as Clarke]; SaAiuelson, Economics 112-15, 118-20 (4th ed. 1958); Hearings on H.R. 9091, 9120, 10283, and 10284 Before the House Committee on Ways and Means, 84th Cong., 2d Sess. 154-55 (1956) [hereinafter cited as 1956 Hearings]; Mandelker, Judicial Review in General Assistance, 6 J. Pub. L. 100, 104 (1957). See generally Willcox, Patterns of Social Legislation: Reflections on the Welfare State, 6 id. at 3 (1957).

238. See Novak v. O'Neal, 201 F.2d 227, 231 n.4 (5th Cir. 1953); cf. 1 Corrrer If 6.02 , at 795; Hearings Before the Honse Committee on the Judiciary, 75th Cong., 1st Sess., ser. 9, at 388-89 (1937).

239. See Vance, Homestead Exemption Lawes, 7 Encxc. Soc. Scr. 441, 442 (1932); Comment, 46 YALE L.J. 1023, 1024 (1937). 
ought to bear the burden of ameliorating the effects of bankruptcy. ${ }^{240}$ State welfare programs, financed from general tax receipts, would spread the costs of economic misfortune more widely, ${ }^{241}$ and perhaps more equitably. Extension of credit is a necessary economic function, and except insofar as they knowingly allow a borrower to overextend himself, lenders are no more responsible for the debtor's financial embarrassment than other members of the community. Moreover, trained welfare personnel could more effectively foster rehabilitation, by helping the bankrupt secure a new job or acquire new skills. Family protection would also be bolstered, since funds would be expended under staff supervision, thus not subject to the debtor's control and possible improvidence. Finally, governmental assistance would presumably be geared to need, while the exemption system permits some debtors to emerge from bankruptcy with more property than is necessary and does not provide for the bankrupt who has no assets out of which to claim an exemption.

But presently existing welfare legislation, as classified into categorical (or special) assistance on the one hand and general assistance on the other, ${ }^{242}$ is probably not an adequate replacement for exemptions. Categorical assistance, administered by the state and frequently supported by the federal government, helps only those persons who, because of status or prior contributions, qualify for payments. ${ }^{243}$ Typically, these programs aid the aged, the blind, the disabled, the unemployed, and the uncared-for child, ${ }^{244}$ and are not, as a rule, predicated on an individual showing of need. ${ }^{245}$ Unless the discharged bankrupt happens to fit in one of these favored groups, he will receive no benefit from such statutes. Although unemployment insurance might appear to offer sustenance to many bankrupts, recent statistics indicate

240. See Hanna \& Maclachlan, Cases on Creditors' Rights and Corporate Reorganization 95 (5th ed. 1957); cf. Burns, Social Security and Public Policy 2 (1956).

241. For costs of assistance programs generally, see BuRNs, op. cit. supra note 240, at 151-248; Friedlander, InTroduction to SOCIAL Welfare 231-32, 241, 571, 581-84, 598-602 (1955) [hereinafter cited as Friedlander]; Tax Foundation; Improving Puglic Assistance (1953).

242. See Clarke 486; Riesenfeld \& Maxwetr, Modern Soctal Legislation 683 (1950); tenBroek, The 1956 Amendments to the Social Security Act: After the New Look-The First Thought, 6 J. PUв. L. 123, 127-29 (1957).

243. See Clarke 486; Riesenfald \& Maxwell, op. cit. supra note 242, at 763; 1956 Hearings 4, 7; Manelker, Judicial Review in General Assistance, 6 J. PuB. L. 100, 102 (1957) Mandelker, Exclusion and Removal Legislation, 1956 Wrs. L. REv. 57, 57 n.2.

244. See S. Rep. No. 1669, 81st Cong., 2d Sess. 3-5, 52-61 (1950); ClarkE 552-642; Mandelker, Judicial Review in General Assistance, 6 J. PuB. L. 100, 102 (1957); Mandelker, The Need Test in General Assistance, 41 VA. L. Rev. 893, 894 (1955).

245. See 1956 Hearings 35; Mandelker, Judicial Review in General Assistance, 6 J. Pub. L. 100, $105 \&$ n.20 (1957) ("[C]riteria of public policy unrelated to need or income maintenance condition the relief of dependent persons to whom the statutes apply."); tenBroek, The 1956 Amendments to the Social Security Act: After the New Look-The First Thought, 6 J. PuB. L. 123, 127-28 (1957). 
that the overwhelming majority are employed wage earners at the time proceedings are initiated. ${ }^{246}$ Thus, the average bankrupt desiring state aid is relegated to reliance on general assistance.

Derived from the English poor laws, general assistance programs furnish temporary cash or commodity allowances to eligible persons. ${ }^{247}$ Although the statutory tests of eligibility vary widely, all require the recipient to demonstrate "need," and some retain the criteria of "pauperism" or "destitution."248 In practice, a relief applicant must have so little property that he is unable to sustain himself and his family, although the more liberal jurisdictions will give aid to those holding some cash and life insurance, or even a modest homestead. ${ }^{249}$ Additional limitations on general assistance as an effective mode of social welfare are the residency requirements in all but eight jurisdictions. ${ }^{250}$ One-year residence is most common, but some statutes demand as much as five years. ${ }^{251}$ Even if the applicant can surmount the residency and necessity barriers, however, he will often find that the relief allowance is inadequate to maintain a standard of living above the most meager subsistence level. ${ }^{252}$ Most programs are designed to enable the recipient to meet only his most immediate and basic needs, with a view toward his early re-

246. Out of 1,327 bankruptcy petitions surveyed for March 1959, 1,061 bankrupts were reported to be employed. See Appendix col. 2.

247. See Burns, The Axrerican Social Security System 339 (1949); Clarke 486; 1956 Hearings 155; Mandelker, Judicial Review in General Assistance, 6 J. PuB. L. 100-01 (1957). See generally Riesenfeld, The Formative Erc of American Public Asistance Law, 43 CALIF. L. Rev. 175 (1955).

248. See Clarke 488-92, 499; Mandelker, Judicial Review in General Assistance, 6 J. Pub. L. 100, 102 (1957); Annot., 98 A.L.R. 870 (1935). See generally Mandelker, The Necd Test in General Assistance, 41 VA. L. Rev. 893 (1955). Many localities will also deny assistance to the "able bodied worker," thus further retarding rehabilitative opportunities. See id. at 907-08.

249. E.g., Wash. Rev. Code Ans. $\$ 74.08 .010$ (11) (Supp. 1957). See Burns, Sucial Security and Public Policy $65-66$ (1956); Clarke 489; Friedrander 254, 255; Mandelker, The Need Test in General Assistance, 41 VA. L. Rev. 893, 895-97, 899 \& n.15 (1955) ; cf. Burns, The American Soctal Security Systenr 341 (1949); Sorieri, Role of the Welfare Department in a Recession, 17 PuB. Welfare 17, 18 (1959).

250. See Clarke 506; Public Assistance, in Reamings in Social Security 498 (1948); Mandelker, The Settlement Requirement in Genteral Assistance, 1955 WASH. U.L.Q. 355,356 n.2.

251. CLARKE 506; FrIedLANDER 255 n.29. The variations among the states are great. Some require residence in the county from which aid is sought, while others insist only upon a state residence. And some require a local residence in addition to the state residence. See Mandelker, The Settlement Requirement in General Assistance, 1955 WASH. U.L.Q. 355, 366-68 \& nn.46-50 (collecting statutes).

252. See Burns, The American Social Security System 346-47, 350-56 (1949); Clarke 490; Mandelker, The Need Test in General Assistance, 41 VA. L. Rev. 893, 90405 (1955). See generally 1956 Hearings 83, 119-20, 121, 138, 142-43; Public Assistance, in Readings in Soctal Security 492 (1948).

Further barriers facing the relief applicant stem from the difficulties in reviewing denials of relief by administrators. See CLARKE 492-96; Mandelker, Judicial Review in General Assistance, 6 J. Pub. L. 100 (1957). 
moval from the relief rolls. ${ }^{253}$ Many state legislators and relief administrators are seemingly wedded to the puritan philosophy that public aid encourages moral weakness, and it should be denied wherever possible. ${ }^{254}$ In fact, some jurisdictions retain the Elizabethan requirement of a "pauper's oath," cause recipient's names to be published and disenfranchise them. ${ }^{255}$ Only recently has the necessity of giving greater attention to the debtor's long-term requirements and his reestablishment as a socially productive person been recognized. ${ }^{256}$

General assistance also suffers from lack of uniformity. Historically the poor laws were the responsibility of the parish-the smallest unit of government-and today general assistance is administered by over 10,000 county and municipal governments. ${ }^{257}$ As a result, disparity in both the availability of aid and the quality of its administration occurs even within the borders of a single state. ${ }^{258}$ Furthermore, most agencies lack both the funds and the trained personnel to adequately investigate an applicant's requirements and supervise his rehabilitation, although some of the larger cities constitute notable exceptions. ${ }^{259}$

253. See Clarke 489; Mandelker, The Need Test in General Assistance, 41 VA. I. Rev. 893, 904-05 (1955); Smith, supra note 245, at 271.

254. See Clarke 493, 499; Martz, Cittzen Participation in Governasent: A Study of County Welfare Boards 20 (1948); 1956 Hearings 141, 143.

255. See, e.g., Dez. Const. art. $5, \S 2$ (pauper not qualified as elector); ME. Const. art. II, $\$ 1$ (same); Mo. CoNsT. art. $8, \S 2$ (vote denied to any person kept in poorhouse at public expense); ConN. Gen. Stat. $\$ \S 17-278$ (oath) 17-291 (names of poor are public records) (1959); Clarke 499; FrIedlander 262-63. For a discussion of the recent trend to make general assistance records public, and the deterrent effect this may have on relief applicants, see Mandelker, Spare the Punishment and Save the Individual: A New Approach to Client Frand in General Assistance, 50 Nw. U.L. Rev. 739, 741-45 (1956).

256. See Mandelker, The Need Test in General Assistance, 41 VA. L. Rev. 893,907 \& n.36 (1955). Congressional passage of the 1956 Social Security Amendments, which were aimed, inter alia, at furthering self-care and self-support in categorical assistance, has given new impetus to services and rehabilitation activity. See Barnard, New $D e$ velopments in Services to PA Recipients, 17 Pur. Welfare 55 (1959); note 261 infra. Although some states have codified attempted rehabilitation programs, e.g., WASH. REv. CODE $§ \S 74.11 .010-.900$ (Supp. 1957), their success is hampered by insufficient funds and lack of trained personnel. See FRIEDLANDER 259-60; 1956 Hearings 310.

257. See Clarke 487; Public Assistance, in Readings in Social Security 491 (1948) ; MARTZ, op. cit. supra note 254; Mandelker, Judicial Review in General Assistance, 6 J. PUB. L. 100, 101 (1957).

258. See ClarKe 487-88; FrIedLANDER 254-55; Mandelker, Indicial Review in General Assistance, 6 J. PuB. L. 100, 102 (1957). The amount of financial aid and supervision furnished by state agencies to localities also varies widely. But where general assistance has been integrated with federally supported categorical assistance, the standards of administration are usually improved. See CLARKE 487-88; Mandelker, supra at $101 \&$ nn. 3, 4, 102.

259. See Clarke 489, 499; Public Assistance, in Readings in Soctal Security 49192 (1948) ; 1956 Hearings 6, 17, 19, 40, 41, 133, 167, 227; Barnard, New Developments in Services to PA Recipients, 17 PUB. WeLFARE 55, 60 (1959); Mandelker, Juddicial Review in General Assistance, 6 J. Pub. L. 100, 120 (1957). 
While a revamping of these programs, or the introduction of new ones, ${ }^{260}$ could conceivably furnish a complete alternative to exemptions, such a course would place upon the government a dual burden of providing interim support and replacing those necessaries surrendered to creditors. Household furnishings, cooking utensils and wearing apparel, for instance, would have to be restored. Substitute housing would have to be secured for those bankrupts whose homestead is surrendered. In addition, when a debtor's livelihood depends upon an automobile, tools, or farm acreage, they would have to be furnished if he is to continue his occupation. Not only would this involve large expenditures of funds and talent, but it would inevitably impose unwanted governmental controls upon many individuals who could, with the aid of exemptions, reconstruct their lives without additional assistance. In striking a balance between laissez-faire and a welfare economy, legislators have sought to relive personal misfortune with a minimum impairment of self-reliance and initiative. ${ }^{201}$ The welfare alternative to exemptions would seem to undercut the philosophy implicit in most welfare legislation: help only to those who cannot help themselves.

With complete reliance on social welfare an inadequate substitute, it is clear that exemptions still have utility in a modern economy. Although this would require creditors to bear the initial burdens of debtor relief, it is perhaps not as unfair to them as might first appear. They have borne them for many years without a noticeable adverse effect upon the growth and operation of the credit system. Although complaints are occasionally lodged against the excessive liberality of a few state statutes, ${ }^{262}$ these criticisms are directed at the magnitude of allowable exemptions, not at their existence. More important than the absence of fundamental criticism, however, is the fact that creditors as a class do not bear the ultimate burden of debtor relief for they are able to

260. For example, proposals have been advanced for the federal government to support local general assistance programs. See FrIEDLANDER 255; 1956 Hearings 92, 95-98, 274-77; Sorieri, Role of the Welfare Department in a Recession, 17 PUB. WeLfare 17, 41 (1959).

261. See tenBroek, The 1956 Amendments to the Social Security Act: After the Now Look-The First Thonght, 6 J. PuB. L. 123, 129 (1957). This policy has been implemented through making receipt of relief payments more difficult. These have included the "less eligibility" principle that grants should never exceed the earnings of the lowest class of independent worker, use of stringent needs tests, limitations on the duration of benefits, availability for substitute employment, and various administrative controls on malingering. See Burns, Social Security and Public Policy 56-79 (1956). Congress, in 1956, codified these heretofore implicit aims by amending the categorical assistance programs specifically to include self-care and self-support in the purposes of federally supported welfare. 70 Stat. $848-50$ (1956), 42 U.S.C. $\$ \$ 301,302(a)(11), 601$, 602(a) (12), 1201, 1202(a) (13), 1351, 1352(a) (12) (Supp. V, 1958); see S. REP. No. 2156, 84th Cong., 2d Sess. 29 (1956).

262. See Hearings Before the House Conmittee on the Judiciary, 75th Cong., 1st Sess., ser. 9, at $38 S$ (1937); 11 N.Y. Jun. Coun. REP. 270 (1945); Krause, What You Should Know About Bankruptcy: A Shield as Well as a Sword!, Student Law. J., Feb. 1959 , p. 24. 
spread the costs to society as a whole through control of the interest rate and the availability of tax deductions for business bad debts. ${ }^{263}$ Finally, the abolition of exemptions would be uneconomical. The debtor's personal property is not likely to bring a large return for creditors when sold on the second hand market. ${ }^{264}$ But much of it will remain useful to the bankrupt. ${ }^{265}$ Continuation of exemptions, however, need not imply a total avoidance of social welfare programs. Bankrupts whose exemptions are insufficient for effective maintenance and rehabilitation, either because they have no exempt assets or because the statutory allowance is too small, will require assistance. Given the similarity in purpose of the two systems, defects in existing exemption legislation should be remedied with social welfare programs-both present and potential-in mind.

\section{Toward a Modern System of Exemptions}

Historically, exemption statutes have been justified in terms of three fundamental policies. Legislators have sought to encourage debtor rehabilitation 200 (e.g., tools-of-the-trade exemptions); to provide minimum security for his family ${ }^{267}$ (e.g., homestead and household necessities) ; and to relieve the community of some of the burdens of social welfare ${ }^{268}$ (e.g., wages and personal property). But exemptions have also been utilized to achieve extraneous goals. Homestead laws, for example, have been used to encourage migration to sparsely populated areas, and to foster home ownership. ${ }^{269}$ Exemptions for church pews, Bibles, and burial lots are based largely on religious considerations. The numerous provisions immunizing farm tools and animals, as well as agricultural acreage and crops, constitute the most obvious use of exemptions to serve a select class of debtors and encourage a particular livelihood.270

263. See INT. Rev. CoDE of 1954, § 166.

264. See In re Richards, 64 F. Supp. 923, 925 n.4 (S.D. Tex. 1946).

265. See Abraham v. Davenport, 73 Iowa 111, 113, 34 N.W. 767, 768 (1887).

266. See In re Hindman, 104 Fed. 331, 333 (9th Cir. 1900); In re Mattingly, 42 F. Supp. 83, 84 (W.D. Ky. 1941) ; Perfection Paint Prods. v. Johnson, 330 P.2d \$29, 830-31

(Cal. Dist. Ct. App. 1958) ; Howell v. Boyd, 2 Cal. App. 486, 490, 84 Pac. 315, 317 (Dist. Ct. App. 1905) ; Talbot v. Scogin, 147 So. 722, 723 (La. Ct. App. 1933).

267. See Estate of Kachigian, 20 Cal. 2d 787, 791, 128 P.2d 865, 867 (1942); In re Keough's Estate, 42 Misc. 387, 392-99, 86 N.Y. Supp. 807, 810-15 (Surr. Ct. 1904); First Nat'l Bank v. Tiffany, 40 Wash. 2d 193, 202, 242 P.2d 169, 173 (1952) ; WApr.Es, Homstead and Exemptions 3 (1893); Haskins, Homestead Exemptions, 63 Harv. L. Rev. 1289 (1950); Comment, 46 YaLE L.J. 1023, 1024 \& n.10 (1937).

268. See Hollywood Credit Clothing Co. v. Jones, 117 A.2d 226, 227 (D.C. Munic. Ct. App. 1955) ; Slatcoff v. Dezen, 76 So. 2d 792, 794 (Fla. 1954) Young v. Geter, 185 La. 709, 715-16, 170 So. 240, 241-42 (1936); Maschke v. O’Brien, 142, Pa. Super. 559, 563, 17 A.2d 923, 924 (1941).

269. See Haskins, supra note 267 , at 1290 ; Comment, 46 Y YLE L.J. 1023, 1031 \& nn.64-69 (1937).

270. Virtually all states make provision for farm equipment and animals. See, e.g., Kan. Gen. Stat. Ann. \$ 60-3504 (1949); Mich. Stat. ANN. \$27.1543 (Supp. 1957); Minn. Stat. Ann. \$\$550.37(6), (11) (Supp. 1958); Mo. Ann. Stat. $\$ 513.435$ (1952); N.Y. Crv. Prac. Act. $\$ \S 665(4)$, (7); Tex. Rev. Crv. Stat. Anv. art. 3832 (1945); Wis. Stat. Ann. $\$ 272.18(6)$ (1958); Annot., 107 A.L.R. 614 (1937). 
A modern exemption program, however, should not require creditors to subsidize such secondary goals as home ownership and the pastoral way of life. But the fundamental policies of exemption legislation-support and rehabilitation for the debtor and his family-remain as crucial today as they were in biblical times. ${ }^{271}$ The overriding problem is thus not one of redefining ends, but of finding modern means to achieve those ends.

Any proposal to reform exemptions must take account of the number of bankruptcies and the typical financial condition of bankrupts. The number of bankruptcy cases oscillated between 15,000 and 25,000 yearly from 1905 to 1921, rose to 70,000 during the 1930's depression, tapered off to a record low of 10,000 in 1946 , and has climbed steadily thereafter. ${ }^{272}$ The fiscal year 1958 saw, for the second successive year, an all-time peak in the number of bankruptcy cases. ${ }^{273}$ Of the more than 91,000 petitions filed, over 80,000 were non-business bankruptcies, and 73,000 of these were employees. ${ }^{274}$ A1though no figures are available to determine precisely how many of the remaining 11,000 business bankruptcies involved corporations, it is probable that a substantial number were unincorporated entrepreneurs and professionals. ${ }^{275}$ The overwhelming majority of the total cases filed were commenced voluntarily, 76,000 as straight bankruptcy proceedings and 13,000 under Chapter

271. See Exodus 22:26-27; Denteronony 24:6, 10-13.

272. U.S. Adninistrattve OfFice of the U.S. Courts, Tables of BankRuptcy Statrstics chart 1 (1958) [hereinafter cited as Bkcx. Startstrcs]. There was, however, a slight dip in the number of cases filed in 1951-1952.

273. BксX. Statistics 1, chart 1. This figure represented an increase of $24.3 \%$ over fiscal 1957. Id. at 1 .

274. Bкxст. Statistics chart 2 , table $F 3$. The nonbusiness bankruptcies increased by 16,647 over fiscal 1957. Nonbusiness filings in 1958 represented $87.6 \%$ of the total bankruptcies, as compared to $86.3 \%$ in 1957 . Id. at 1 .

275. Cf. Appendix. The Tables of Bankruptcy Statistics prepared by the Administrative Office of the United States Courts in accordance with $\S 53$ of the Bankruptcy Act are broken down into the following occupational classifications :

From table F 3

\begin{tabular}{lcc}
\hline \hline Occupation & Voluntary & Involintary \\
\hline Farmer & 332 & $\dagger$ \\
Employee & 73,379 & $\dagger$ \\
Professional & 281 & 3 \\
Others not in business & 6,870 & 16 \\
Merchant & 2,922 & 582 \\
Manufacturer & 562 & 196 \\
Others in business & 5,904 & 621 \\
$\quad$ Totals & 90,250 & 1,418
\end{tabular}

tFarmers and wage earners are not subject to involuntary proceedings. Bankruptcy Act $\$ 4(\mathrm{~b})$. Farmer is defined in $\S 1(17)$. Compare the definition of wage earner in $\S 1(32)$ for purposes of involuntary bankruptcy with the definition of wage earner in $\$ 606(8)$ for purposes of eligibility for Chapter XIII Wage Earner plans. 
XIII's Wage Earner Plan, providing for a court supervised arrangement procedure enabling the debtor to satisfy his obligations over an extended period rather than to extinguish them. ${ }^{276}$ The balance were either involuntary straight bankruptcies $(1,413)$ or under the chapters relating to special arrangements and reorganizations (816). ${ }^{277}$ These figures indicate that the typical 1958 bankrupt was a wage earner who voluntarily initiated proceedings.

The second crucial pattern that emerges from an analysis of bankruptcy statistics is that liquidation provides virtually no recovery for general creditors. Of the 66,000 estates administered in fiscal 1958 under the straight bankruptcy provisions of the act, $49,000(74 \%)$ had no assets whatever above allowable exemptions, $8,600(13 \%)$ had some nonexempt property, but no assets remained after the payment of administrative expenses, and only 8,500 $(13 \%)$ had net assets for distribution to creditors. ${ }^{278}$ But even in this last category creditors fared badly. Overall, only eighteen per cent of allowable claims were paid: the secured claimants realizing seventy per cent of their claims, the priority claimants thirty-three per cent, and the unsecured creditors (with seventy-four per cent of all provable debts) only seven cents on the dollar. 279

\section{Who Are the Bankrupts?}

Unfortunately, statistics concerning the type and amount of claimed exemptions have been unavailable. To obtain this information, the Yale Law Journal

276. BKcy. STATISTICs 2 , table F 2. The voluntary straight bankruptcies increased by $26 \%$ over 1957 . Id. at 1 .

The wage earner proceeding is voluntarily commenced by filing a petition stating that the debtor is a wage earner (as defined by Bankruptcy Act $\$ 606(8)$ ), that he is unable to pay his debts as they mature and that he desires to enter into a composition or extension, or both, out of his future earnings. A plan is submitted with the petition for confirmation by the court. The confirmation order generally appoints a trustee, fixes the amount to be paid and the mode of distribution, and directs the employer to pay the trustee. See Bankruptcy Act $\$ \S 601-86$. For more detailed descriptions of wage earner plans, see 9 CoLLIER fff 21.01-33.05; Allgood, Chapter XIII: Wage Earners' Plans, 15 REF. J. 20 (1940); Banks, The Forgotten Remedy: Wage Earners' Plans Under the Bankruptcy Act, 33 N.C.L. Rev. 439 (1955); Bundschu, Administration of Wage Earners' Plans in the Bankruptcy Court, 18 REF. J. 55 (1944); Bundschu, Proceedings under Chapter XIII, 25 id. 15 (1951); Maulitz, Operations under Chapter XIII, 27 id. 68 (1953); Rice, The Trustee under Chapter XIII, 30 id. 102 (1956); Sloan, Wage Earners' Plans, 33 id. 5 (1959); Woodbridge, Wage Earners' Plans in the Federal Courts, 26 Minn. L. Rev. 775 (1942).

277. Brcx. Statistics table F 2. Of the voluntary petitions, 2 were filed under Chapter IX, dealing with municipal debt readjustments, 62 were filed under Chapter $\mathrm{X}$, the corporate reorganization provisions, 724 were filed under Chapter XI, dealing with arrangements for small corporations and individuals, and 23 were filed under Chapter XII, dealing with real property arrangements by persons other than corporations. Five involuntary petitions were filed under Chapter X. Ibid.

278. BKCY. Statrstics 2. The number of no asset cases increased 11,094 over 1957, while the number of nominal asset cases increased by only 2,081 . Id. at 4 .

279. Bксу. Statistrcs table F 6. 
sent a questionnaire to one hundred four district court clerks, requesting data on the first twenty-five individual petitions filed in March 1959. Seventy-eight questionnaires from forty-four jurisdictions, containing figures on 1,327 bankrupts, were returned. ${ }^{280}$ These responses reveal the following facts: almost eighty per cent of all bankrupts were employed by others at the time of filing the petition; just under ten per cent were apparently self-employed; and just over ten per cent were either involuntarily unemployed or not available for work. $^{281}$ Over eighty-eight per cent claimed some exempt property, but the range was enormous-from just a few dollars to over $\$ 35,000 .{ }^{282}$ The same disparity is disclosed if, in those states reporting five or more bankruptcies (40), the two lowest claimed exemptions (excluding bankrupts who claim no exceptions) are averaged and compared with the two highest claims. Nationally, these figures are $\$ 161$ and $\$ 5,831$ respectively. ${ }^{283}$ Similar disparity exists among the states: the average exemption claimed by Maryland bankrupts is $\$ 188$, while Florida claims averaged $\$ 7,427.284$ Nationally, the average individual claim for all bankrupts (including those who claimed no exemptions) was $\$ 943.285$

The questionnaire also sought to determine what items are most typically claimed as exempt. Eighty per cent of the bankrupts polled claimed household goods and wearing apparel, for an average value of $\$ 343 .{ }^{286}$ Twelve per cent claimed a homestead, averaging $\$ 3,568$ in value. ${ }^{287}$ Tools of the trade were

280. The Yale Law Journal wishes to thank the clerks of the United States District Courts for their time and cooperation. Although results are tabulated for only forty-four jurisdictions, one questionnaire was received from Alaska too late for inclusion, and one from South Carolina reported no bankruptcy filings for the period.

The questionnaire took the form of a chart requesting the following information for each petition: occupation of the bankrupt; whether bankrupt is employed; amount of liabilities; amount of assets; whether asset figure includes exempt property; total claimed exemptions; value of household furniture and wearing apparel claimed; value of homestead claimed; value of insurance claimed and whether claim is at face or cash value; value of tools of the trade claimed; whether other sizeable exemptions are claimed, and if so, a description of type and value. This information was obtained from the bankruptcy schedules filed by each voluntary and involuntary bankrupt. The questionnaire directed the Clerks to the relevant schedule for each item of information requested. The returned questionnaires are on file in Yale Law Library. The resulting tabulations are presented in an appendix at the end of the Comment [hereinafter cited as AppENDrx].

281. See Appendix cols. 2 (employed), 4 (self-employed), 3 (unemployed).

282. See AppeNdrx cols. 1, 7. The highest individual claim of $\$ \$ 1,700$ was made by a Florida haberdasher. But if his claim of insurance at $\$ 45,000$ face value is deducted, the amount is $\$ 36,700$.

283. See AppENDIX cols. 8 , 9. The national averages were obtained by adding the figures in cols. $S$ and 9 , and dividing each total by 40 (the number of jurisdictions reporting 5 or more bankrupts).

284. See Appendix col. 10.

285. See APPENDIX cols. 1, 11. There were, however, only 208 bankrupts (15.7\%) who claimed more than $\$ 1,000$. Id. col. 6 .

286. See Appendix cols. 12, 13.

287. See Appendix cols. 14, 15. 
claimed by nine per cent, at an average value of $\$ 445 .^{288}$ (But if the $\$ 17,400$ claim of a Washington State fruit and vegetable wholesaler is eliminated, the national average is reduced to $\$ 303$. $)^{289}$ Seventy bankrupts, or five per cent, claimed life insurance as exempt. ${ }^{290}$ The average value was difficult to determine, however, since the face value of the policy, rather than the cash surrender, is often stated in the petition. In the thirty-one instances where cash value was specified, the claimed exemptions averaged $\$ 1,053 .{ }^{291}$ In addition, 337 petitions, or twenty-five per cent, claimed an automobile averaging $\$ 309$ in value. ${ }^{292}$ Finally, the data were analyzed to determine whether self-employed bankrupts claimed higher than average exemptions. Comprising approximately ten per cent of all bankrupts, they claimed twenty-five per cent of all exemptions, averaging $\$ 2,485$ - or almost three times that of the overall average. ${ }^{203}$

Perhaps the most significant conclusion emerging from these figures is that one fixed method of determining exemptions should not be applied to all bankrupts. If exemptions are geared to the needs of the typical bankrupt-the wage earner who rents his home and has a modest amount of furniture and clothingthey will not provide the self-employed with sufficient capital to start another business or buy another farm. Conversely, if they are large enough to facilitate the entrepreneur's rehabilitation, the wage earner will retain more assets than necessary, and creditors' expectations will be needlessly defeated. Finally, exemptions, no matter how computed, are of no help to the bankrupt who lacks the figurative shirt on his back. Consequently, three potentially overlapping categories of bankrupts must be considered in choosing reform: the entrepreneur who needs a capital allowance for rehabilitation, the wage earner who needs a moderate amount of personal property for his maintenance, and the debtor who has no assets whatever.

Conceivably, the varying needs of these groups could be met by providing differing exemptions to each of them. Thus, the self-employed would surrender fewer assets for distribution to his creditors than the employee. But such a distinction is administratively unworkable. It would be difficult or impossible to determine at the time of bankruptcy which entrepreneurs will resume their trade, and which will become another's employee, or retire. Conversely, an employee who intended to go into business for himself after discharge would

288. See Appendix cols. 20, 21.

289. Ibid.

290. See Appendix cols. 16, 17.

291. See Appendix cols. 16, 18. The average value of the face amounts claimed was $\$ 6,605$. See Appendix cols. 17, 19.

292. See Appendrx cols. 22, 23. Unlike its treatment of household goods, the Journal Questionnaire did not include a column requesting information on whether or not an automobile was claimed as exempt. But the Questionnaire, in a sample answer, listed a car as an "other exemption" of significant value. Automobile exemptions present particular problems. Many jurisdictions do not specifically exempt automobiles, while those that do, may permit them under various classifications, thus making analysis difficult. See note 64 supra.

293. See Appendix cols. 4, 5. 
seem equally entitled to the larger exemption. But he also could not be feasibly isolated.

Therefore, a tripartite approach is indicated. Exemptions should be set at a uniform level for all debtors, high enough to enable the average bankrupt to maintain a respectable if modest standard of living. Bankrupts who wish to resume or assume an independent calling might qualify for government assistance in the form of a capital loan. And those who lack any assets even after the allowance of exemptions should be able to resort to welfare assistance.

\section{Uniform Cash Exemption}

Abolition of the exemption of specific assets is the most fundamental step in the attainment of a modern exemption system. The bankrupt should surrender all of his property to the trustee and be accorded a dollar allowance out of its value. He could realize this allowance or use it in whole or in part to "repurchase" any relinquished items he wishes to retain. With the cash, he could procure items necessary for his family's support or start a new lifeperhaps by moving to another community, acquiring a skill or trade, or investing in a business venture. This course has several advantages. It treats bankrupts equally, without regard to whether their assets-either by chance or by design-meet the statutory description of exempt property. Consequently, converting nonexempt property on the eve of bankruptcy would no longer be profitable. ${ }^{204}$ Secondly, it avoids all problems of recovery of exempt assets under the avoiding sections of the Bankruptcy Act, for there would no longer be a distinction between "exempt" and "nonexempt."295 Thirdly, exemptions would never become anachronistic, for money, unlike animals and turnips, always measures wealth accurately. ${ }^{29 B}$ Moreover, a cash exemption can reflect alterations in the dollar's purchasing power, either by periodic amendment, or more profitably, by automatic annual changes, geared to some economic indicator such as per capita income or a retail price index. ${ }^{297}$ Since the cost of living varies materially in different geographical areas, ${ }^{298}$ Congress could conveniently choose economic indicators computed on a state or regional basis. Thus geographical exemption would accurately reflect geographical economic variety.

Exemption uniformity could be accomplished in three ways: the existing policy allocating responsibility for exemptions to the states could be retained and revised; the current framework could be abandoned in favor of a uniform federal exemption; or a compromise between the two established. Although

294. See text at notes $140-48$ supra.

295. See text at notes 154-219 supra.

296. See text at notes $57-62$ supra.

297. See Comment, 26 Calif. L. Rev. 466, 471 (1938).

298. See U.S. Bureau of the Census, Dep't of Commerce, Statistical Abstract of THE UNITED StaTES 333-35 (1958). 
significant improvements can be made within the present statutory pattern by modernizing state exemptions and removing inconsistencies in the Bankruptcy Act, lack of uniformity, conflicts of law problems and difficulties engendered by the contracts clause-to list only the most obvious disadvantages-would remain. Admittedly, the adoption of a uniform state exemption would meet many of these objections. But the difficulties in obtaining local amendment, and particularly a uniform codification, are enormous, ${ }^{209}$ especially in this area, where the alteration of state policies is likely to evoke emotional controversy. More fundamentally, however, traditional state exemption statutes could not be adapted to a cash exemption system, for they invariably go to an individual creditor's rights, not a total liquidation and distribution of a debtor's estate. For example, were state statutes to make available to creditors all assets except $\$ 1,000$ in cash or property, an inventory of the debtor's assets would be required every time a creditor attempted to attach or levy. ${ }^{300}$ Conceivably, states might enact a separate bankruptcy exemption ${ }^{301}$ in terms of a cash allowance, but this is unlikely. A second alternative would be a compromise based on the Bankruptcy Act of $1867 .{ }^{302}$ This would entail a minimum federal exemption to ensure essential family protection and debtor rehabilitation, but would recognize state exemptions in excess of the federal minimum. Although this approach would give some recognition to regional variations, the goals of equal treatment and uniform administration would be defeated. Furthermore, in those states, such as California, which provide extremely liberal exemptions, the federal policy fostering the repayment of debts would be subserved.

Consequently, the best way to accomplish the primary goals of relief and rehabilitation appears to be a uniform federal cash exemption. Such an exemption is neither unprecedented nor constitutionally objectionable. ${ }^{303}$ Bankruptcy is a federal function, specifically delegated to Congress in the Constitution. ${ }^{304}$

299. Of the 109 uniform and model acts approved by the National Conference of Commissions on Uniform State Laws, 30 have not been adopted by any jurisdiction. Of the 79 acts adopted in one or more jurisdictions, 57 have been accepted in less than half. See Tables of States Adopting Acts in 1-10 U.L.A. (1957); cf. Gilmore, On the Difficulties of Codifying Commercial Law, 57 Y YLE L.J. 1341 (1948).

300. Generally, all the debtor must do at present is make his claim in writing when the exempt asset is levied upon. E.g., Cat. Civ. Proc. Code Ans. $\S 690.26$ (1) (1955); ILI. REv. STAT. ch. 52, \$ 14 (1957). An appraisal of the asset's value may occur either when it is claimed, Mo. AnN. Stat. § 513.445 (1952); Wis. Stat. Anv. § 272.19 (1958), or when an execution creditor complains that its value is greater than the allowable exemption, Ilt. Rev. Stat. ch. 52, § 10 (1957); Wis. Stat. ANn. § 272.21 (1958).

301. No state appears to have a separate bankruptcy exemption at this time, and only Virginia seems to make any conscious effort to coordinate part of its exemption statute to bankruptcy. See VA. Cone ANN. \$ 34-17 (1953).

302. See Bankruptcy Act of $1867, \S 14,14$ Stat. 522-23.

303. See Novak v. O'Neal, 201 F.2d 227, 231 n.4 (5th Cir. 1953) ; 1 ColLIER $\llbracket 6.02$, at 795 .

304. U.S. Const. art. I, § 8. 
And exemptions are integral to any bankruptcy legislation. Indeed, the Bankruptcy Acts of $1800^{305}$ and $1841^{306}$ both specified federal exemptions without reference to state practice, and it was in fact the provisions of the 1867 and 1898 acts, incorporating local law, that met challenge on the ground that those exemptions did not provide "uniform Laws on the subject of bankruptcies" as constitutionally commanded. ${ }^{307}$

The amount of a uniform exemption is a delicate political question to which this Comment cannot provide a firm answer, but guides for Congress may be suggested. Through investigation, Congress could determine the minimum needs of persons making fresh beginnings in life: discharged servicemen, recent graduates, ex-convicts, and newlyweds, as well as bankrupts. To balance the fact that discharged bankrupts may own used assets of a low market value, and thus not start completely anew, Congress could take into consideration the minimum accumulations of property by solvent wage earners. The data available to the Yale Law Journal suggests that an effective cash exemption could be on the order of $\$ 1,000$. This would allow the debtor to reclaim his household goods and wearing apparel-which averaged, prior to bankruptcy, $\$ 350$ in value. ${ }^{308}$ In addition, he could keep (or secure) a $\$ 300-500$ automobile, necessary tools, or a modest life insurance policy, as well as a small amount of cash to meet special needs or emergencies. To this might be added a special allowance for a married bankrupt (say $\$ 300$ ) and each child that he supports (perhaps $\$ 1 C 0$ ), as well as an allowance for the unemployed debtor who is no longer entitled to unemployment compensation. A relatively low exemption could encourage more wage earners-the typical bankruptto take advantage of the Bankruptcy Act's wage earner plan. ${ }^{309}$ Under Chapter XIII, the debtor can retain his property, while entering into a court supervised plan for repayment of his debts out of his single significant asset-his future wages. ${ }^{310}$ Such a composition achieves the goal of rehabilitation with-

305. Bankruptcy Act of $1800, \S 5,2$ Stat. 23 .

306. Bankruptcy Act of $1841, \S 3,5$ Stat. 442.

307. See Hanover Nat'l Bank v. Moyses, 186 U.S. 181, 188-90 (1902) (1898 Act); I in re Deckert, 7 Fed. Cas. 334, 336 (No. 3728) (C.C.E.D. Va. 1874) (1867 Act); In re Beckerford, 3 Fed. Cas. 26, 27 (No. 1209) (C.C.D. Mo. 1870) (same).

308. See Appendix col. 13.

309. Bankruptcy Act $\S \S 601-86$.

310. Since the primary concept is that the debtor effect the composition or extension out of his future earnings, the court is vested with exclusive jurisdiction over the debtor's earnings and wages during the period of the plan. Bankruptcy Act $\S 611$. Exclusive jurisdiction over the debtor's property is also obtained. Ibid. To enable the debtor to consummate the plan, proceedings against his property may be enjoined or stayed. Bankruptcy Act $\$ \S 614,625$. Thus, so long as the debtor continues the plan, he will be able to retain his property. Cf. City Nat'l Bank \& Trust Co. v. Oliver, 230 F.2d 686 (10th Cir. 1956). If the plan fails of completion the court may order that bankruptcy be proceeded with pursuant to the act. Bankruptcy Act $\S 666$. And if the debtor has properly claimed his exemptions, they are preserved to him as under $\$ 6$. Bankruptcy Act $\S 637$. 
out the necessity of a liquidation, and often ensures greater creditor recovery without undue damage to the debtor. ${ }^{311}$

The proposed federal exemption will necessarily become interrelated with state statutes immunizing property from attachment and levy. In those states whose provisions are less than the federal allowance, voluntary bankruptcies will become more attractive. Thus, the inadequacies of state law can be surmounted. Where state exemptions exceed the federal grant, however, creditors will seek to institute involuntary proceedings, rather than rely on state execution procedures. But there can be no such proceedings absent an act of bankruptcy by the debtor ${ }^{312}$ Since the sufferance of a lien is such an act, the paramountcy of a federal policy of creditor satisfaction (while providing for adequate debtor relief) could be ensured, if no other act of bankruptcy is available to the creditors, by a new wrinkle on the "hypothetical lien" concept. Section 3(a) (3) could be amended to provide that the requisite act is deemed to have been committed whenever a debtor has property, valued in excess of the federal allowance, which is free from a lien only because of its exempt status under state law. Thus the creditors could utilize section 3(a)(3) to furnish the basis of an involuntary petition just as if one of them was in the group which may attach otherwise exempt property, ${ }^{313}$ and in whose favor a lien hypothetically attached.

Plus Aid to the Pauper-Bankrupt. The most serious rehabilitation problem is the bankrupt who has little or no assets. An exemption canot help him, no matter what form it assumes. The close relationship between the aims of exemptions and social welfare and the desirability of providing for all bankrupts suggests that the bankruptcy court should automatically refer the pauper-debtor to the appropriate local agencies. By itself, however, referral is not enough, for welfare allowances are sometimes unavailable, often too meager, ${ }^{314}$ and of no help to the individual who needs a lump sum rather than a small weekly allowance. Since bankruptcy is a federal responsibility, it would be appropriate for the national government to supplement state aid to bankrupts.

311. See Allgood, Chapter XIII-Referee Allgood of Alabama Replies to Referee Walker, 33 ReF. J. 51 (1959); Covey, What's Happening in Bankruptcy, 32 id. 76, 79 (1958); Sloan, Wage Earners Plan, 33 id. 5, 6 (1959). See also articles cited note 276 supra. For criticisms of Wage Earner Plans, see Maclachlan, BankRupTCY 374 75 (1956); Walker, Is Chapter XIII a Milestone on the Path to the Welfare State?, 33 REF. J. 7 (1959).

312. The six acts of bankruptcy are: (1) a fraudulent transfer; (2) a preferential transfer; (3) suffering or permitting a creditor to obtain a lien; (4) a general assignment for the benefit of creditors; (5) the appointment of a receiver; (6) the admission in writing of inability to pay debts and willingness to be adjudged a bankrupt. See Bankruptcy Act $\$ 3$.

The involuntary petition must be filed by three or more creditors whose claims aggregate more than $\$ 500$. But if the debtor has less than twelve creditors, then any one of them whose claim is more than $\$ 500$ may file the petition. See Bankruptcy Act $\$ 59$.

313. See notes 77-83 supra and accompanying text.

314. See notes 250-52 supra and accompanying text. 
For example, all persons whose property available for an exemption claim is worth substantially less than the uniform exemption could be referred to the appropriate local agency, who would determine what assets the bankrupt needs most, and furnish funds in an amount approaching the uniform figure. Where desirable, the agency would control the expenditure of the funds. The money thus advanced plus applicable administrative expenses would then be charged to the federal government. This expenditure can be financed from the general revenues or from a special fund, analogous to the referees' salary and expense fund, derived from bankruptcy filing fees. ${ }^{315}$

Plus Aid to the Entrepreneur-Bankrupt. A uniform cash exemption suited to the needs of the typical bankrupt would also prove inadequate for entrepreneurs wanting to start afresh. The policy of encouraging the self-employed to continue his occupation is implicit in many current exemption provisionsmost clearly in the case of farm acreage, equipment and livestock. The Yale Law Journal questionnaire indicates the success of these statutes; selfemployed bankrupts were, on the average, able to exempt almost three times as much property as their brethren. ${ }^{316}$ If this policy is to be continued under a uniform cash exemption system, capital funds could be most efficiently secured from public sources, such as a federal agency which would lend (or perhaps give) money to discharged bankrupts with the experience and initiative necessary to successfully prosecute a new venture.

While somewhat persuasive criticisms of the proposed capital-assistance program may be put forth, they ignore equally or more compelling arguments on the other side. Thus it may be said that bankrupts are per se poor credit risks. ${ }^{317}$ But during a national or regional slump, many able businessmen fail, and in generally prosperous times, bankruptcies may result from a declining trade or unsuitable farmland. Nor does it follow that the man who makes one fatal mistake in judgment is bound to make another. Those bankrupts who are in fact poor risks would simply not qualify for a loan. Similarly, the argument that the government should not become a rival of private lenders disregards the various existing federal programs designed to allow and en-

315. Each petition filed must be accompanied by a filing fee of $\$ 45$. Bankruptcy Act $\S 40$ (c) (1) provides that $\$ 17$ of the fee shall go to the referees' salary fund and $\$ 15$ shall go to the referees' expense fund. These fees are supplemented by additional fees based upon the net proceeds realized from the estate. Bankruptcy Act $\S 40(\mathrm{c})$ (4); Bankruptcy ACT 60-63 (Collier pamphlet ed. 1956). At the end of fiscal 1958 both funds had a combined surplus of over $\$ 6$ million. BKCY. STATISTICs letter of transmittal.

316. See Appendix. Column 5 (total claimed by self-employed) is deducted from column 11 (total claimed exemptions). Column 4 (number of self-employed) is then deducted from column 1 (number of bankrupts). The quotient obtained by dividing these two remainders is compared with the quotient obtained by dividing the total of column 5 by the total of column 4 .

317. Cf. Malspies, Public Capitalization of New Business, 10 MIAMI L.Q. 1, 13 (1955) (bankruptcy is one of the factors considered by the Small Business Administration in evaluating a loan applicant's good character). 
courage economic rebirth through grant and loan..$^{318}$ Indeed, this rivalry is more imaginary than real, since private lenders will not usually make loans to bankrupts. ${ }^{319}$

The administration of a federal capital assistance program could be assigned to the Small Business Administration, whose operations are analogous. The SBA makes short term loans to qualified enterprises when private credit is unavailable..$^{320}$ Long term credits and equity capital will also be available, as a result of the Small Business Investment Act of 1958, from private investment companies, initially financed with SBA funds. ${ }^{321}$ The proposed program, however, would necessitate an alteration and enlargment of the SBA's present functions. Current classifications of size for "small business" 322 would have to be reevaluated to encompass sole proprietors with very few, if any, employees. Also, the present practice of making loans only to going businesses would have to be abandoned..$^{323}$

Once established, a bankruptcy division of the SBA should make capital funds available to discharged bankrupts whether or not they were self-employed immediately prior to bankruptcy. Of course, all applicants would have to establish their experience and capacity to run a business, and prepare-with

318. See, e.g., Homestead Acts, 12 Stat. 392 (1862), as amended, 43 U.S.C. §§ 161301 (1952); Servicemen's Readjustment Act of 1944 (G.I. Bill of Rights), 58 Stat. 284 (codified in scattered sections of 38 U.S.C.); Small Business Act, 67 Stat. 232 (1953), as amended, 15 U.S.C.A. $\$ \S 631-47$ (Supp. 1958).

319. Existing programs are usually not in conflict with private lenders, for they are limited to situations where private funds are unavailable at reasonable terms. See, e.g., Small Business Act, 72 Stat. 388, 15 U.S.C.A. § 636(a) (1) (Supp. 1958); SAULNIER, HaICrow \& Jacoby, Federal Lending and LoAN Insurance 72 (1958); Malspies, supra note 317, at 9,12; McCallum, Loans by the Small Business Administration, 13 Bus. Law. 349-50 (1958).

320. The Small Business Administration, successor to the Reconstruction Finance Corporation, was established in 1953. 67 Stat. 232 (1953), as amended, 15 U.S.C.A. §§ 631-47 (Supp. 1958). See generally Baum, The Small Business Administration: Some Potential Problems, 27 U. CInc. L. Rev. 270 (1958); Malspies, supra note 317; McCallum, supra note 319; Schoen, The Small Business Administration, 17 MD. L. REv. 30 (1957).

321. 72 Stat. 689 , 15 U.S.C.A. $\$ 661-96$ (Supp. 1958); see H.R. REP. No. 2060, 85th Cong., 2d Sess. (1958); S. Rep. No. 1652, 85th Cong., 2d Sess. (1958); Conf. Rep. No. 2492, 85th Cong., 2d Sess. (1958).

322. The statute defines a small business concern as "one which is independently owned and operated and which is not dominant in its field of operation." 72 Stat. 384, 15 U.S.C.A. \& 632 (Supp. 1958). Authority is granted to the Administrator to use other criteria in making a more detailed definition. Ibid. Having found that a single definition is unrealistic, the SBA has adopted flexible categories that vary by industry. See 21 Fed. Reg. 9709 (1956), 22 Fed. Reg. 2121, 3314, 4190 (1957), 23 Fed. Reg. 2636, 3099 (1958), 24 Fed. Reg. 1246, 2090, 2091 (1959), 13 C.F.R. $\$ \S 121.3-1$ to -8 (1959). But it would seem that existing classifications are more concerned with setting the upper limits of size and volume than with the problems of the very small business. See Baum, supra note 320, at 270-75; Malspies, supra note 317, at 9-10.

323. Cf. id. at 9-10. 
agency assistance-plans demonstrating the proposed projects' feasibiility..$^{324}$ To ensure that funds are economically employed, they should be available only to persons willing to make the effort necessary for economic success. Consequently, long term loans at, or near, the commercial rate of interest would seem preferable to outright gifts. ${ }^{325}$ If the plan proves workable, it might be expanded to assist other bankrupts who need funds to acquire new skills or further education, to move to a more prosperous area, or to apply to other rehabilitative purposes.

\section{Safeguarding Family Security}

Problems of the exemption system itself aside, the Bankruptcy Act should be amended to realize more effectively the exemption goal of security for a bankrupt's dependents. At present the discharged family is insufficiently protected: the debtor can dispose of his exempt assets irresponsibly. Under the proposed uniform cash exemption system, the typical bankrupt-neither pauper nor entrepreneur-would get unsupervised control of the funds. Although a few states have attempted to safeguard the family, ${ }^{326}$ the methods of control are imprecise and some of the consequences undesirable. For example, state statutes barring alienability of homesteads without the consent of both spouses ${ }^{327}$ only prevent the debtor from encumbering or disposing of one type of property, and in so doing serves to clog credit.

A more comprehensive approach to family protection might be based on the British example. Under the English bankruptcy act, the trustee may grant the debtor periodic allowances for family support during pendency of the proceedings, subject to review by a creditors' inspection committee. ${ }^{328}$ The American statute could adopt this approach by substituting the bankruptcy court for the inspection committee. The court could advise the bankrupt's dependents of the availability of periodic allowances. If special protection is needed, they could petition for guardianship, and the necessity

324. Similar evidence of the applicant's abilities and the probability of repayment must be shown under the existing program. See $i d$. at 14; McCallum, supra note 319 , at 350-51.

325. The present SBA requirement that loans be secured or of sound financial value may have to be somewhat relaxed. If the SBA were to use the same criteria as banks do, the discharged bankrupt would never receive a loan. For criticism of current SBA practice, see Baum, supra note 320, at 275-78.

326. See, e.g., ILI. Rev. Stat. ch. 52, \$§ 2, 15 (1957) (exemption continues for remaining spouse after death or desertion); Mo. ANN. STAT. $\$ 513.450$ (1952) (wife may claim if husband absconds or absents himself); W. VA. CoDE ANN. $\$ 3899$ (1955) (either spouse may claim exemption); WIs. Stat. ANN. $\$ 272.20$ (1958) (homestead can be claimed by either spouse). See generally Joslin, Bankruptcy from a Family Laze Perspective, 9 VAND. L. REV. 789 (1956).

327. See, e.g., LA. Const. art. 11, § 3; Ariz. Rev. Stat. Ann. § 33-1104 (1956); Ill. Rev. Stat. ch. 52, $\$ 4$ (1957); Mo. Ann. Stat. $\$ 513.475(2)$ (1952).

328. The Bankruptcy Act, $1914,4 \& 5$ Geo. 5 , c. 59, $\S 58$; see 1 Collurer $\Uparrow 6.01$, at 793; Williams, BankRuptcy 424 (17th ed. 1958). 
thereof would be decided by the court. Supervisory jurisdiction following discharge might similarly be ordered, if necessitated by an irresponsible head of a household. Such a case could be referred to a local welfare agency, which would return any remaining assets to the debtor or his spouse when solvency is achieved.

\section{Summary}

The purposes of exemption legislation cannot be fully achieved under the current system of federal incorporation of state exemptions; they are both too varied and too outmoded. Specific-asset exemptions fail to reflect presentday standards of wealth-holding. A policy of even-handed debtor relief and rehabilitation dictates a cash exemption, federally enacted and tied to an accurate economic indicator. The special problems posed by the entrepreneuror pauper-bankrupt could be solved by the proposed capital loan and social welfare program.

The last comprehensive revision of the Bankruptcy Act took place twentyone years ago.329 And over sixty years have elapsed since passage of the Act of 1898 which gave effect to state exemptions in bankruptcy. Congressional re-examination of bankruptcy exemptions is long overdue.

329. The Chandler Act, 52 Stat. 840 (1938) (codified in scattered sections of 11 U.S.C.), was a major revision of the Bankruptcy Act of 1898, 30 Stat. 544. 


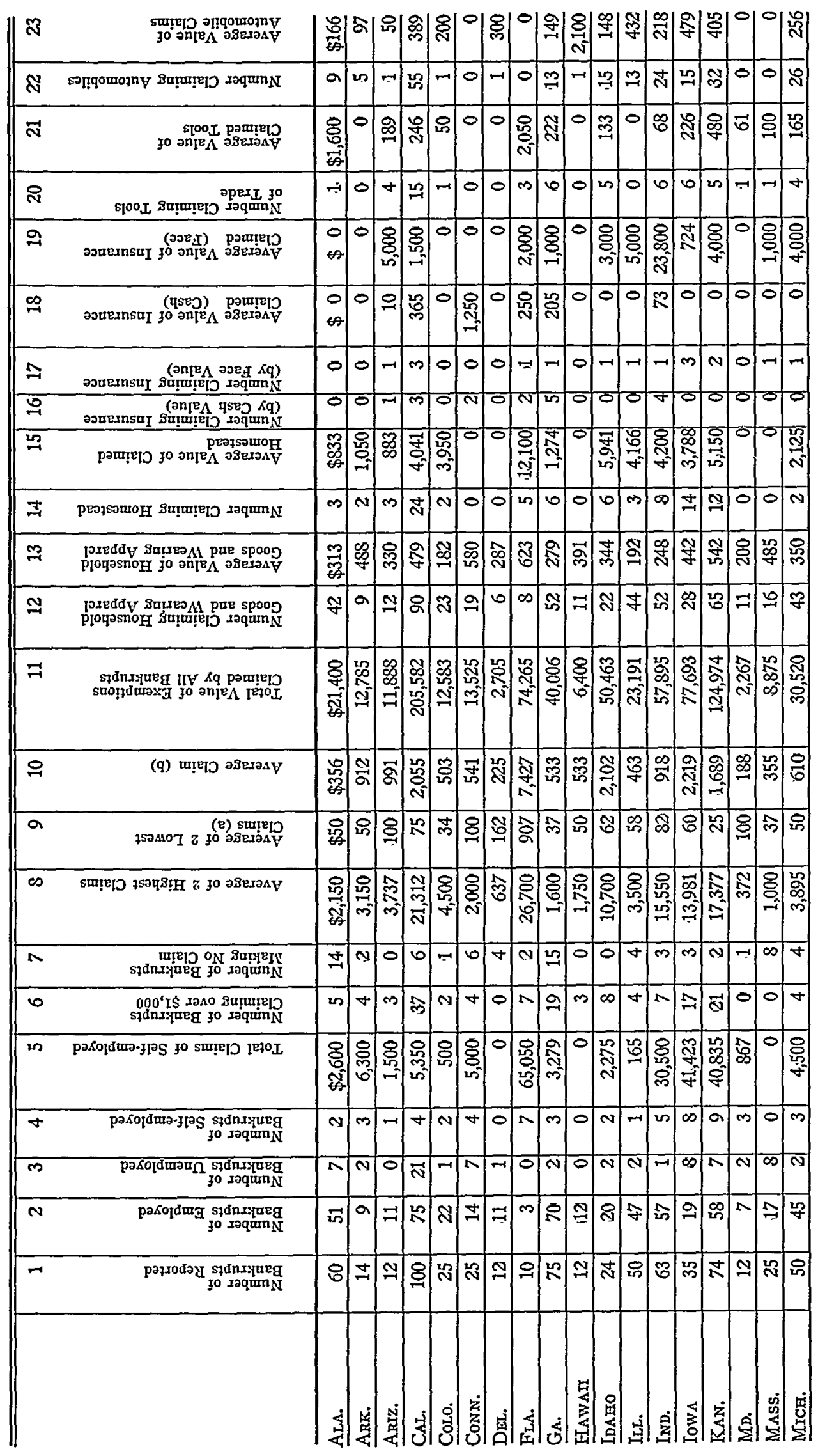


||

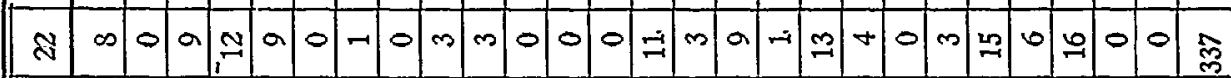

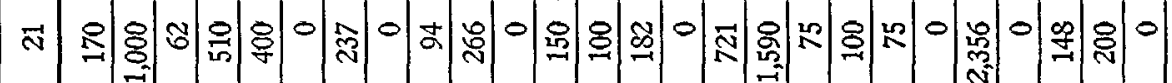

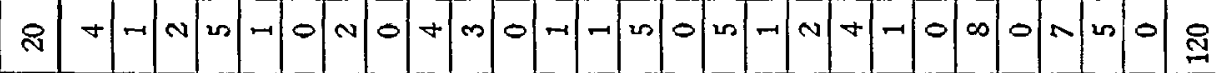

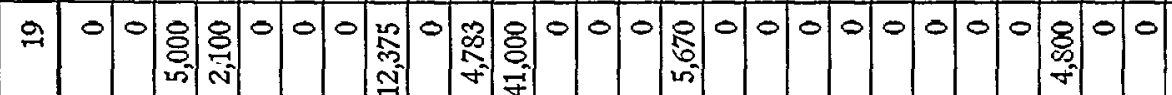
$\stackrel{\infty}{\sim}$ \&

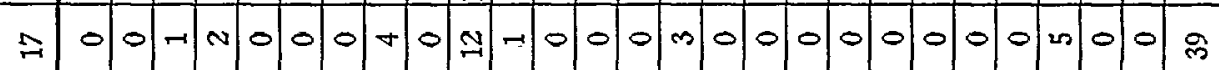

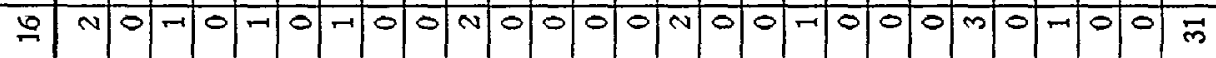

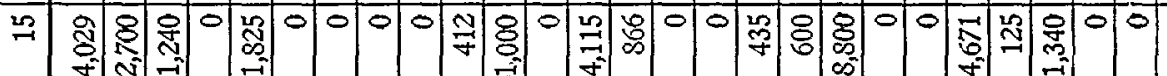

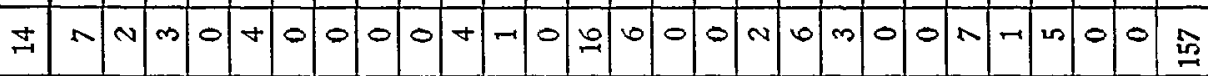

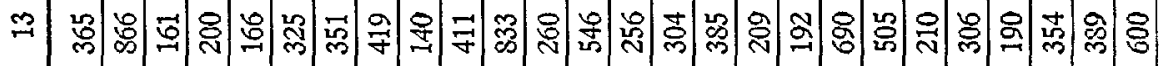

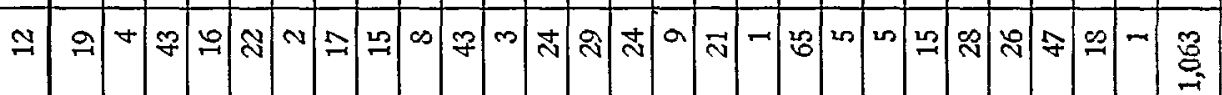

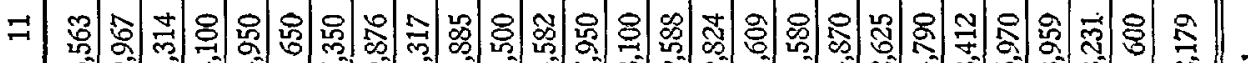
की $\Rightarrow$ जी

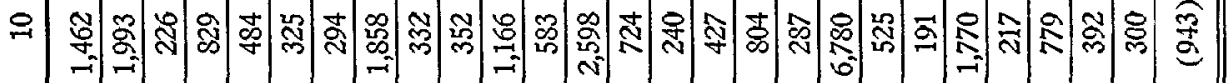
을 융

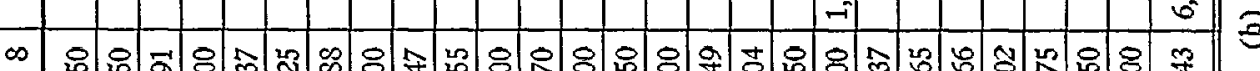

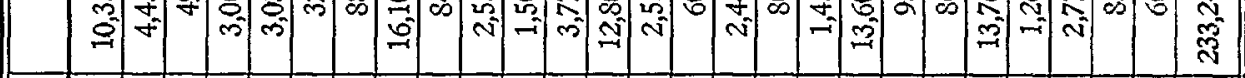
$n+0$ N 0 o v 0 a

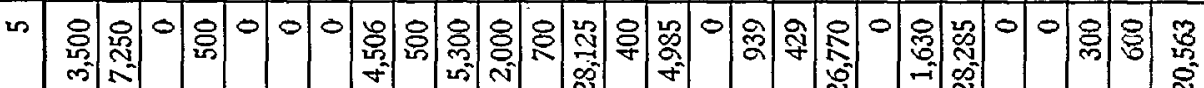

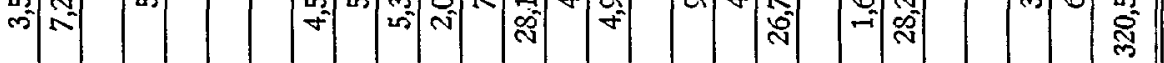

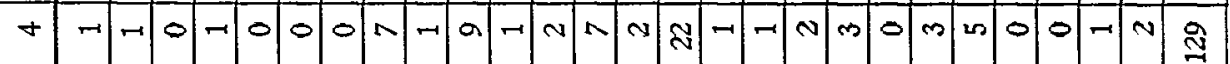
m nom nmogn-

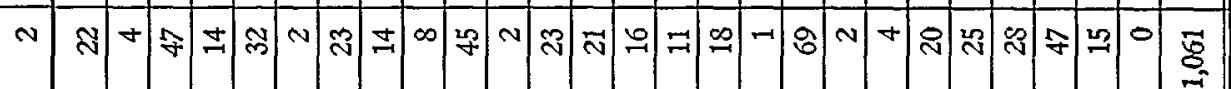

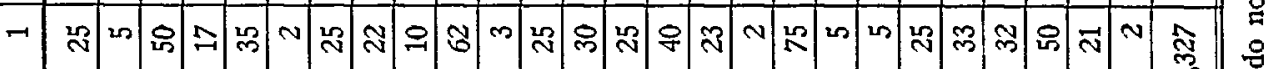

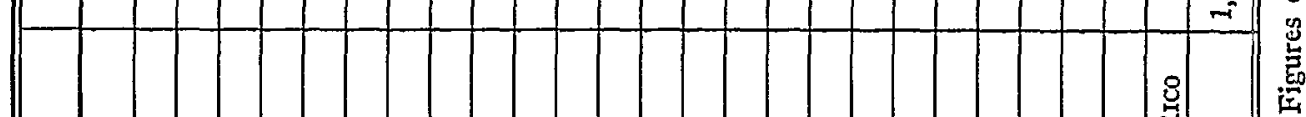

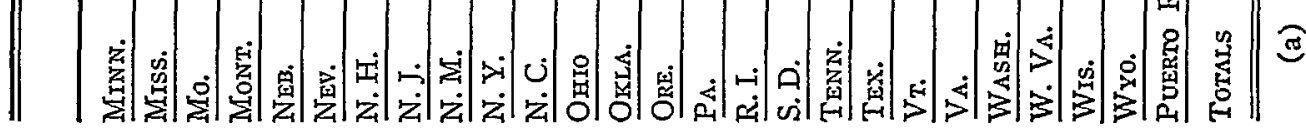

